Article

\title{
Genome Sequence and Analysis of the Flavinogenic Yeast Candida membranifaciens IST 626
}

\author{
Margarida Palma ${ }^{1,2,3, * \mathbb{D} \text {, Stephen Mondo }}{ }^{4,5}$, Mariana Pereira ${ }^{1,2}$, Érica Vieira ${ }^{1,2}$, Igor V. Grigoriev ${ }^{4,6}$ \\ and Isabel Sá-Correia $1,2,3$ (D)
}

Citation: Palma, M.; Mondo, S.; Pereira, M.; Vieira, É.; Grigoriev, I.V.; Sá-Correia, I. Genome Sequence and Analysis of the Flavinogenic Yeast Candida membranifaciens IST 626. Fungi 2022, 8, 254. https://doi.org/ $10.3390 /$ jof 8030254

Academic Editors: Ricardo

Franco-Duarte and Celia Pais

Received: 30 January 2022

Accepted: 27 February 2022

Published: 1 March 2022

Publisher's Note: MDPI stays neutral with regard to jurisdictional claims in published maps and institutional affiliations.

Copyright: (C) 2022 by the authors. Licensee MDPI, Basel, Switzerland. This article is an open access article distributed under the terms and conditions of the Creative Commons Attribution (CC BY) license (https:// creativecommons.org/licenses/by/ $4.0 /)$.
1 Institute for Bioengineering and Biosciences, Instituto Superior Técnico, Universidade de Lisboa, Av. Rovisco Pais, 1049-001 Lisboa, Portugal; mariana.r.pereira@tecnico.ulisboa.pt (M.P.); erica.vieira@tecnico.ulisboa.pt (É.V.); isacorreia@tecnico.ulisboa.pt (I.S.-C.)

2 Department of Bioengineering, Instituto Superior Técnico, Universidade de Lisboa, Av. Rovisco Pais, 1049-001 Lisboa, Portugal

3 Associate Laboratory i4HB-Institute for Health and Bioeconomy at Instituto Superior Técnico, Universidade de Lisboa, Av. Rovisco Pais, 1049-001 Lisboa, Portugal

4 US Department of Energy Joint Genome Institute, Lawrence Berkeley National Laboratory, Berkeley, CA 94720, USA; sjmondo@lbl.gov (S.M.); ivgrigoriev@lbl.gov (I.V.G.)

5 Department of Agricultural Biology, Colorado State University, Fort Collins, CO 80523, USA

6 Department of Plant and Microbial Biology, University of California Berkeley, Berkeley, CA 94720, USA

* Correspondence: margarida.palma@tecnico.ulisboa.pt

\begin{abstract}
The ascomycetous yeast Candida membranifaciens has been isolated from diverse habitats, including humans, insects, and environmental sources, exhibiting a remarkable ability to use different carbon sources that include pentoses, melibiose, and inulin. In this study, we isolated four $C$. membranifaciens strains from soil and investigated their potential to overproduce riboflavin. $C$. membranifaciens IST 626 was found to produce the highest concentrations of riboflavin. The volumetric production of this vitamin was higher when C. membranifaciens IST 626 cells were cultured in a commercial medium without iron and when xylose was the available carbon source compared to the same basal medium with glucose. Supplementation of the growth medium with $2 \mathrm{~g} / \mathrm{L}$ glycine favored the metabolization of xylose, leading to biomass increase and consequent enhancement of riboflavin volumetric production that reached $120 \mathrm{mg} / \mathrm{L}$ after $216 \mathrm{~h}$ of cultivation. To gain new insights into the molecular basis of riboflavin production and carbon source utilization in this species, the first annotated genome sequence of C. membranifaciens is reported in this article, as well as the result of a comparative genomic analysis with other relevant yeast species. A total of 5619 genes were predicted to be present in C. membranifaciens IST 626 genome sequence (11.5 Mbp). Among them are genes involved in riboflavin biosynthesis, iron homeostasis, and sugar uptake and metabolism. This work put forward C. membranifaciens IST 626 as a riboflavin overproducer and provides valuable molecular data for future development of superior producing strains capable of using the wide range of carbon sources, which is a characteristic trait of the species.
\end{abstract}

Keywords: Candida membranifaciens; Debaryomycetaceae; yeast isolation; soil; riboflavin; flavinogenic yeasts; iron metabolism; xylose assimilation

\section{Introduction}

Candida membranifaciens is an anamorphic yeast first described as Candida melibiosi var. membranifaciens by Lodder \& Kreger-van Rij [1]. Based on the examination of strains assigned to Candida melibiosi var. membranifaciens, C. melibiosi var. melibiosi, and C. guilliermondii, Wickerham and Burton observed that the variety membranifaciens was unable to mate and able to ferment melibiose more vigorously than C. melibiosi [2]. Candida melibiosi var. membranifaciens was proposed as the new species C. membranifaciens. More recently, upon phylogenetic analysis of the D1/D2 domains of the large subunit and the nearly complete 
small subunit rRNA genes from species that express the coenzyme Q-9 form, C. membranifaciens was phylogenetically placed in the Yamadazyma clade of Debaryomycetaceae family [3]. Currently, this species is taxonomically allocated to the Yamadazyma/Candida clade.

Candida membranifaciens strains have been isolated from diverse habitats, including fresh, marine, and estuarine waters, insects, plants, and clinical specimens [4,5]. This species has the ability to assimilate a wide variety of carbon sources that include hexoses (glucose and galactose), pentoses (xylose and arabinose), $\alpha$-glucosides (maltose, trehalose, melezitose), $\beta$-glucosides (cellobiose, salicin), $\beta$-fructosides (sucrose, inulin), and $\alpha$-galactosides (raffinose, melibiose) [4]. It is also able to grow on media with high osmolarity [4], consistent with its presence in marine environments. Another interesting physiological attribute was found in one strain isolated from seawater, Candida membranifaciens subsp. flavinogenie W14-3, described as a flavinogenic yeast [6]. Regardless of all those remarkable features, its biotechnological potential is poorly explored. For instance, riboflavin production by other C. membranifaciens strains has not been studied.

Riboflavin is a precursor of the coenzymes flavin mononucleotide (FMN) and flavin adenine dinucleotide (FAD), being required for biochemical reactions in all living cells $[7,8]$. It is produced by plants and by the majority of the microorganisms, but humans and animals are unable to synthesize this vitamin, which makes riboflavin an essential component of their diet [9]. In 2012, the annual production of riboflavin worldwide was $9000 \mathrm{t}$, of which about $70 \%$ were used as animal feeding additive and the remaining $30 \%$ as a food additive and in pharmaceutical applications [10]. Although, in industry, riboflavin can be produced by chemical or biological synthesis, the bio-based synthesis has replaced chemical synthesis due to economic and environmental reasons [11]. The bioprocesses that dominate riboflavin production use the Gram-positive bacterium Bacillus subtilis and the hemiascomycete filamentous fungi Ashbya gossypii [10]. The industrial production of riboflavin by the yeast Candida flareri (formerly Candida famata, teleomorph Debaryomyces subglobosus) has also been considered, but it was interrupted due to the genetic instability of industrial strains [12,13]. Other flavinogenic yeast species include Meyerozyma guilliermondii (formerly, Pichia guilliermondii), C. albicans, C. parapsilosis, C. tropicalis, Schwanniomyces occidentalis, Debaryomyces hansenii, and C. membranifaciens subsp. flavinogenie [6,12-15]. These species are also members of the Debaryomycetaceae family and belong to the CTG clade, where CTG codon is predominantly translated as a serine instead of a leucine [16]. Another interesting observation is that these flavinogenic yeasts overproduce riboflavin only under iron-limiting conditions [17]. The influence of iron availability in flavinogenesis has long been a topic of debate $[6,12,18]$, but the mechanisms underlying riboflavin overproduction in response to iron depletion are still poorly understood.

Microorganisms are considered overproducers of riboflavin when they accumulate over $10 \mathrm{mg} / \mathrm{L}$ of this vitamin [12]. Based on the degree of riboflavin accumulation, microorganisms can fall into three categories: weak (10-100 mg/L), moderate (up to $600 \mathrm{mg} / \mathrm{L}$ ), and strong (more than $1 \mathrm{~g} / \mathrm{L}$ ) overproducers [15]. Moderate overproducers are, for example, the species mentioned above from the genera Candida, Debaryomyces, and Meyerozyma that can accumulate the referred riboflavin concentrations upon culture media optimization. Strong overproducers, such as B. subtilis, A. gossypii, and C. flareri, can accumulate more than $10 \mathrm{~g} / \mathrm{L}$ riboflavin [19-21]. Overproducing strains have been developed and selected mainly using random or site-directed mutagenesis or by overexpressing genes involved in riboflavin biosynthesis and these genetic manipulations were combined with culture medium optimization [11]. C. membranifaciens subsp. flavinogenie W14-3 is a weak overproducer; after the optimization of culture conditions, this strain was able to accumulate $22 \mathrm{mg} / \mathrm{L}$ of riboflavin in the growth medium [22]. This value is remarkably below the $20 \mathrm{~g} / \mathrm{L}$ reported to be produced by a mutagenized, although unstable, C. flareri strain [21] Nevertheless, there is still room for the selection and development of new overproducer yeasts, with potential for stable riboflavin production from raw materials other than defined media. Yeasts can offer some technological advantages over filamentous fungi, including low growth requirements, easier distribution of the cells along the fermenter, and the 
possible use of yeast biomass as a source of protein [23]. Therefore, the identification of novel riboflavin yeast overproducers and their physiological and molecular characterization are essential steps to gain new insights into relevant unclear issues. This is the case of the regulation of riboflavin secretion and accumulation in the culture medium, the characterization of the unknown phosphatase that catalyzes the dephosphorylation of 5-amino-6-ribitylamino-2, $4(1 \mathrm{H}, 3 \mathrm{H})$ pyrimidinedione 5 -phosphate in riboflavin biosynthetic pathway, and the physiological role of riboflavin overproduction under iron-limiting conditions. Moreover, from a circular bioeconomy perspective, the selection of new yeast strains able to effectively use organic residues as alternative feedstocks for the production of added-value compounds such as riboflavin is a topic to be pursued.

In this work, we isolated four C. membranifaciens strains from soil and investigated their potential to overproduce riboflavin and C. membranifaciens IST 626 was found to produce the highest amounts of riboflavin. Riboflavin production by this strain was optimized by manipulating growth medium composition. The genome of C. membranifaciens IST 626 was sequenced and annotated. A comparative genomic analysis with other relevant yeast species is also provided.

\section{Materials and Methods}

\subsection{Isolation and Identification of Candida membranifaciens Isolates}

Candida membranifaciens isolates were obtained from three soil samples collected in Arrábida Natural Park, Sesimbra, Portugal ( $38^{\circ} 26^{\prime} 12.4^{\prime \prime}$ N, $\left.9^{\circ} 04^{\prime} 05.0^{\prime \prime} \mathrm{W}\right)$; Berlengas Biosphere Reserve, Berlenga Grande, Portugal $\left(39^{\circ} 24^{\prime} 59.0^{\prime \prime}\right.$ N, $\left.9^{\circ} 30^{\prime} 23.7^{\prime \prime} \mathrm{W}\right)$; and Ferreira do Alentejo, Portugal $\left(38^{\circ} 02^{\prime} 43.6^{\prime \prime} \mathrm{N}, 8^{\circ} 06^{\prime} 34.3^{\prime \prime} \mathrm{W}\right)$. For yeast isolation, three cycles of culture enrichment were performed to avoid growth of filamentous fungi, as previously described [24]. Approximately one gram of each soil sample was inoculated in $50 \mathrm{~mL}$ of growth medium containing: $3 \mathrm{~g} / \mathrm{L}$ malt extract (Sigma-Aldrich, Burlington, MA, USA), $3 \mathrm{~g} / \mathrm{L}$ yeast extract (ThermoFisher), $5 \mathrm{~g} / \mathrm{L}$ peptone (ThermoFisher), $1 \mathrm{~g} / \mathrm{L}\left(\mathrm{NH}_{4}\right)_{2} \mathrm{SO}_{4}$ (Panreac), $0.25 \mathrm{~g} / \mathrm{L} \mathrm{KH}_{2} \mathrm{PO}_{4}$ (Panreac, pH 5.0), $30 \mathrm{~g} / \mathrm{L}$ of glucose (Scharlau), and $30 \mathrm{~g} / \mathrm{L}$ of xylose (Sigma-Aldrich). This growth medium with the soil sample was supplemented with chloramphenicol $\left(100 \mu \mathrm{g} / \mathrm{mL}\right.$ ) and incubated at $30^{\circ} \mathrm{C}$ at $150 \mathrm{rpm}$ for $48 \mathrm{~h}$ (First Enrichment). Then, $1 \mathrm{~mL}$ of this culture was added to $49 \mathrm{~mL}$ of the same medium, and incubated again at $30{ }^{\circ} \mathrm{C}, 150 \mathrm{rpm}, 48 \mathrm{~h}$ (Second Enrichment). To differentiate yeasts with the ability to grow in different carbon sources, a differential enrichment step was performed, where $1 \mathrm{~mL}$ from the Second Enrichment culture was added to $49 \mathrm{~mL}$ of the same medium but containing either $60 \mathrm{~g} / \mathrm{L}$ glucose or $60 \mathrm{~g} / \mathrm{L}$ xylose and incubated in the same conditions as before. After $48 \mathrm{~h}$ of cultivation, the samples were diluted in $0.85 \% \mathrm{NaCl}$ solution and poured into isolation agar medium. This medium includes $3 \mathrm{~g} / \mathrm{L}$ yeast extract (ThermoFisher), $5 \mathrm{~g} / \mathrm{L}$ peptone (ThermoFisher), $1 \mathrm{~g} / \mathrm{L}\left(\mathrm{NH}_{4}\right)_{2} \mathrm{SO}_{4}$ (Panreac), $0.25 \mathrm{~g} / \mathrm{L} \mathrm{KH}_{2} \mathrm{PO}_{4}$ (Panreac), and $20 \mathrm{~g} / \mathrm{L}$ agar (NZYtech), with either $60 \mathrm{~g} / \mathrm{L}$ glucose or $60 \mathrm{~g} / \mathrm{L}$ xylose [24], and was supplemented with chloramphenicol $(100 \mu \mathrm{g} / \mathrm{mL})$. Plates were incubated at $30{ }^{\circ} \mathrm{C}$ for $48 \mathrm{~h}$. Yeast cells from colonies with different morphologies were observed on an Axioplan microscope $\left(\times 1000\right.$ magnification) (Zeiss $\left.{ }^{\circledR}\right)$ and streaked into new agar plates to assure the purity of the isolate. Yeast isolates were maintained at $4{ }^{\circ} \mathrm{C}$ until DNA extraction was performed. For long-term storage, isolates were preserved at $-80{ }^{\circ} \mathrm{C}$ in their isolation medium containing $15 \%(v / v)$ glycerol.

For the molecular identification of yeast isolates, genomic DNA was extracted using the phenol:chlorophorm:isoamyl alcohol method [25] and used as a template for the amplification by polymerase chain reaction (PCR) of the D1/D2 domain sequence of the $26 \mathrm{~S}$ and the internal transcribed spacer (ITS) region of ribosomal DNA (rDNA). The primers' pairs NL-1 (5'-GCATATCAATAAGCGGAGGAAAAG-3') and NL-4 (5'-GGTCCGTGTTTCAAGACGG-3'), and ITS1 ( $5^{\prime}$-TCCGTAGGTGAACCTGCGG-3') and ITS4 (5'-TCCTCCGCTTATTGATATGC-3'), known to be effective for the taxonomic identification of yeasts [26], were used in the amplification of D1/D2 and ITS regions, respectively. The two DNA fragments from each isolate were purified using NZYGel pure (NZYtech, Portugal) and Sanger-sequenced (Stabvida, 
Portugal) using each corresponding primer. The molecular taxonomic identification was performed by comparing D1/D2 and ITS sequences with others deposited in GenBank using the BLAST algorithm from the National Center for Biotechnology Information (NCBI) (http:/ / www.ncbi.nlm.nih.gov/blast, accessed on 30 October 2019). The consensus sequences from D1/D2 region of C. membranifaciens strains IST 495, IST 498, IST 507, and IST 626 were deposited in GenBank under the accession numbers MZ614941, MW003712, MW003715, and MW532700, respectively. The consensus sequences from ITS region of $C$. membranifaciens strains IST 495, IST 498, IST 507, and IST 626 were deposited under the accession numbers MZ615411, MW003718, MW003721, and MW532702, respectively.

\subsection{Phylogenetic Analysis}

For the phylogenetic placement of C. membranifaciens strains isolated in this study, their D1/D2 domain of LSU rDNA sequence were aligned iteratively with the sequences of related species from Debaryomycetaceae family, retrieved from the GenBank under the accession numbers indicated in the phylogenetic tree, by using the multiple alignment tool Muscle [27]. The software MEGA-X v.10.2.2 was used for phylogenetic tree construction using the maximum likelihood method of the Tamura-Nei evolutionary model [28]. The confidence level of the clades was estimated using bootstrap analysis with 1000 replicates.

\subsection{Yeast Strains Tested and Growth Media and Conditions Used}

Candida membranifaciens strains IST 495, IST 498, IST 507, and IST 626, isolated and identified as described herein, were examined in this study. We also used C. membranifaciens PYCC $2525^{\mathrm{T}}$ obtained from the Portuguese Yeast Culture Collection (PYCC). The basal growth media used in this study were prepared with either $6.9 \mathrm{~g} / \mathrm{L}$ of commercial yeast nitrogen base without amino acids (mentioned hereafter as YNB) or $6.9 \mathrm{~g} / \mathrm{L}$ yeast nitrogen base without amino acids and without iron (mentioned hereafter as YNB-Fe), both from Formedium $^{\mathrm{TM}}$ (United Kingdom), supplemented with $20 \mathrm{~g} / \mathrm{L}$ glucose (Merck) or $20 \mathrm{~g} / \mathrm{L}$ xylose (Sigma-Aldrich). All media and solutions were prepared using Milli- ${ }^{\circledR}{ }^{\circledR}$ water (Merck Millipore) and all growth assays were carried out in $50 \mathrm{~mL}$ shake flasks containing $25 \mathrm{~mL}$ of medium. Pre-cultivation of yeast cells was performed in either YNB or YNB-Fe with $20 \mathrm{~g} / \mathrm{L}$ glucose for $24 \mathrm{~h}$ at $30{ }^{\circ} \mathrm{C}$ with orbital shaking $(250 \mathrm{rpm})$. After pre-cultivation, yeast cells were harvested by centrifugation $(5000 \mathrm{~g}, 5 \mathrm{~min})$ and inoculated at an initial optical density (OD) at $600 \mathrm{~nm}$ of $0.1 \pm 0.05 \mathrm{in} 25 \mathrm{~mL}$ of the medium to be tested. To investigate the ability of different $C$. membranifaciens strains to produce riboflavin, yeast cells were inoculated in either YNB or YNB-Fe with $20 \mathrm{~g} / \mathrm{L}$ glucose for $120 \mathrm{~h}$ under the growth conditions described above. To evaluate the impact of iron supplementation in the production of riboflavin, C. membranifaciens IST 626 cells were inoculated in YNB-Fe with $20 \mathrm{~g} / \mathrm{L}$ of glucose, to which increasing concentrations of iron (III) chloride $(+0.5 \mu \mathrm{M}$, $+0.8 \mu \mathrm{M},+1.0 \mu \mathrm{M},+1.2 \mu \mathrm{M},+1.5 \mu \mathrm{M},+2.0 \mu \mathrm{M})$ were added. Riboflavin, biomass $\left(\mathrm{OD}_{600 \mathrm{~nm}}\right)$ and glucose concentrations were determined after $120 \mathrm{~h}$ of growth. Cells inoculated in YNB with $20 \mathrm{~g} / \mathrm{L}$ of glucose were used as a control. To evaluate the impact of different sugars and glycine supplementation of the growth medium on riboflavin production by $C$. membranifaciens IST 626, cells were cultivated in YNB-Fe media containing either $20 \mathrm{~g} / \mathrm{L}$ glucose or $20 \mathrm{~g} / \mathrm{L}$ xylose as a carbon source and supplemented with $1 \mathrm{~g} / \mathrm{L}$ or $2 \mathrm{~g} / \mathrm{L}$ glycine (Sigma-Aldrich).

\subsection{Quantification of Riboflavin}

Extracellular riboflavin was determined using a spectrophotometric method as previously described $[29,30]$, but with minor modifications. Briefly, a volume of $1 \mathrm{~mL}$ of each culture was harvested and centrifuged at 10,000 rpm for $3 \mathrm{~min}$ to remove cells. Supernatants were mixed in $0.1 \mathrm{~N} \mathrm{HCl}$ using the appropriate dilution, and riboflavin concentrations were determined by reading the absorbance of each sample at $445 \mathrm{~nm}$ in a spectrophotometer (Hitachi U-2001) and the riboflavin calibration curve performed using several dilutions of a pure riboflavin (Sigma-Aldrich) stock solution $(0.2 \mathrm{~g} / \mathrm{L})$. 


\subsection{Genome Sequencing, Assembly, and Annotation}

Genomic DNA from C. membranifaciens IST 626 was sequenced in an Illumina Novaseq 6000 platform, producing $2 \times 150$-bp paired-end reads. Library preparation $\left(\mathrm{NEBNext}{ }^{\circledR}\right.$ DNA Library Prep Kit from NewEngland Biolabs, Inc., Ipswich, MA, USA) and sequencing were carried out by Novogene Bioinformatics Technology Co., Ltd. (Hong Kong). Illumina sequencing produced 21,753,322 raw paired-end reads. Low-quality bases and adapters were removed using BBDuk from BBMap package (http:/ /jgi.doe.gov/data-and-tools / bb-tools/, accessed on 30 June 2020). Read duplicates were removed using PRINSEQ (v0.20.4) (6). Ultimately, 17,196,026 high-quality reads were used for subsequent analysis. Correction of the reads and assembly into scaffolds were performed using SPAdes (v3.14.0) (7). Scaffolds smaller than $2000 \mathrm{bp}$ were filtered out, and the remaining sets of scaffolds were used as draft assemblies. Assembly quality was analyzed using Quality Assessment Tool for Genome Assemblies (QUAST; v4.6.3) (8). The final assembly consists of 56 contigs, with a total length of $11,508,125$ bases, which includes a mitochondrial DNA contig with $28,672 \mathrm{bp}$. The sequencing reads were deposited in Sequence Read Archive (SRA) under the accession number PRJNA777779, and the sequences obtained in the genome assembly were deposited in GenBank under the accession number JAKQXL000000000. During submission to NCBI, three scaffolds were determined to be contaminants and were excluded. The genome was annotated using the JGI Annotation pipeline [31], made available in JGI fungal genome portal MycoCosm (https: / / mycocosm.jgi.doe.gov/Canmem1, accessed on 25 February 2022).

\subsection{Analysis of Genome Content}

Gene prediction was performed by using the tools available at MycoCosm, the JGI's web-based fungal genomics resource, at the JGI portal [31]. The functional analysis of predicted genes was based on the eukaryotic orthologous groups of proteins (KOG) classification [31,32]. Proteins involved in riboflavin biosynthesis and transport, as well as the proteins involved in iron homeostasis and transport were analyzed using the Annotation and Blast analysis tools from JGI. Members of sugar porter family (2.A.1.1) present in the genome of $C$. membranifaciens IST 626 were obtained based on JGI data for transporter annotations [31], which uses the Transport Classification (TC) system [33,34]. Glycoside hydrolases were obtained based on CAZy annotations [34] also available at MycoCosm.

\subsection{Search for Putative Transcription Factor Binding Sites}

Putative transcription factor (TF) binding sites were searched for in promoter regions of $C$. membranifaciens selected genes using YEASTRACT $+[35,36]$. This database contains all known regulatory associations between transcription factors and target genes in different yeast species for which the information is available in the literature, which means, essentially, for Saccharomyces cerevisiae. YEASTRACT+ includes genomic information on the flavinogenic yeast species C. albicans [14]. The sequences of promoters of interest were retrieved from MycoCosm at the JGI portal [31,37] and inserted into the "Find TF Binding Site(s)" tool of YEASTRACT+ portal (http:/ / yeastract-plus.org/pathoyeastract/calbicans, accessed on 30 June 2021). The analysis was performed using documented TF binding sites from C. albicans.

\section{Results and Discussion}

\subsection{Isolation and Identification of Candida membranifaciens Isolates}

In this study, four different isolates were isolated from the superficial layer of three different soils, two of them from reserve areas in Arrábida Natural Park and Berlengas islands. For those isolations, a rich and undefined growth medium containing glucose and xylose was used for the first two enrichment steps and either one of these sugars was used in the third enrichment step [24]. Strains IST 626, IST 495, and IST 507 were isolated in a medium where xylose was the carbon source present in the third enrichment step, 
whereas strain IST 498 was isolated when glucose was the carbon source present in that enrichment step.

The isolates were identified based on the comparison of their D1/D2 and ITS sequences with the sequences deposited in the NCBI database. The sequences shared 100\% identity with the corresponding $C$. membranifaciens sequences, and the isolates were considered of the C. membranifaciens species. The phylogenetic analysis, based on D1/D2 domain of LSU rDNA sequence, placed the isolates close to C. membranifaciens NRRL Y-2089 ${ }^{\mathrm{T}}$ $\left(=\right.$ PYCC $\left.2525^{\mathrm{T}}\right)$ and the flavinogenic W14-3 strain on Yamadazyma/Candida clade (Figure 1). The closest species to the $C$. membranifaciens clade is $C$. friedrichii [3].

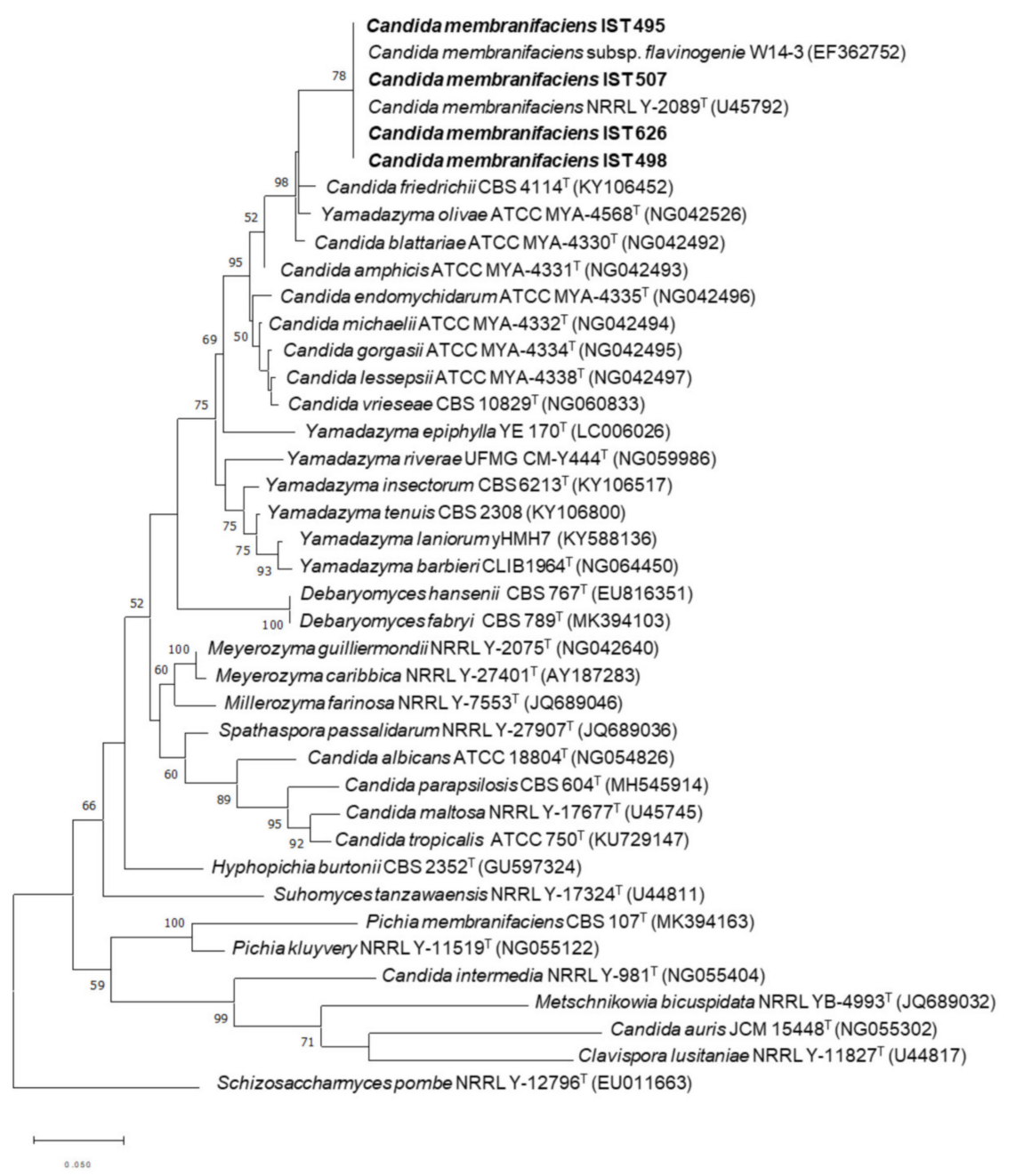

Figure 1. Phylogenetic placement of C. membranifaciens strains IST 495, IST 498, IST 507, and IST 626 isolated in this study. Phylogenetic analysis was based on the alignment of sequences of the D1/D2 domain of the 26S rDNA region, inferred by using the maximum likelihood method and Tamura-Nei model. Sequences from the type strains (superscript T) of different yeast species were included. GenBank accession numbers are shown in parentheses. The strains isolated in this study are highlighted in bold. The scale bar indicates the number of expected substitutions per site. The numbers provided on branches are frequencies with which a given branch appeared in 1000 bootstrap replications. The tree was rooted with Schizosaccharomyces pombe.

The natural habitat of C. membranifaciens is not defined, but isolates from this species have been retrieved from diverse habitats and substrates, including fresh, marine, and estuarine waters, insects, plants, and clinical specimens [4,5]. Yeasts of Candida genus have been isolated from soils worldwide [19,38-40], but, to the best of our knowledge, this is the first report on the isolation of the species C. membranifaciens from this habitat. Interestingly, 
in our study, four strains from this species were isolated from three different soils, showing that soil is a reservoir of this species.

\subsection{Candida membranifaciens Isolates Are Riboflavin Producers}

C. membranifaciens IST 626 was able to produce over $10 \mathrm{mg} / \mathrm{L}$ riboflavin when cultured in YNB with $20 \mathrm{~g} / \mathrm{L}$ of glucose (Figure 2a). The other strains tested produced lower concentrations of the vitamin under the same conditions (Figure 2a). When the five strains examined were cultured in YNB-Fe, all strains except PYCC $2727^{\mathrm{T}}$ overproduced riboflavin (produced more than $10 \mathrm{mg} / \mathrm{L}$ ). C. membranifaciens IST 626 produced the highest concentration of this vitamin, which reached approximately $20 \mathrm{mg} / \mathrm{L}$ after $120 \mathrm{~h}$ of cultivation (Figure 2b). These results indicate that, contrary to C. membranifaciens PYCC $2727^{\mathrm{T}}$, the four C. membranifaciens strains isolated in this study are flavinogenic. Moreover, the results confirm that the presence of iron has a marked negative impact on riboflavin production by C. membranifaciens, consistent with previous observations [6].
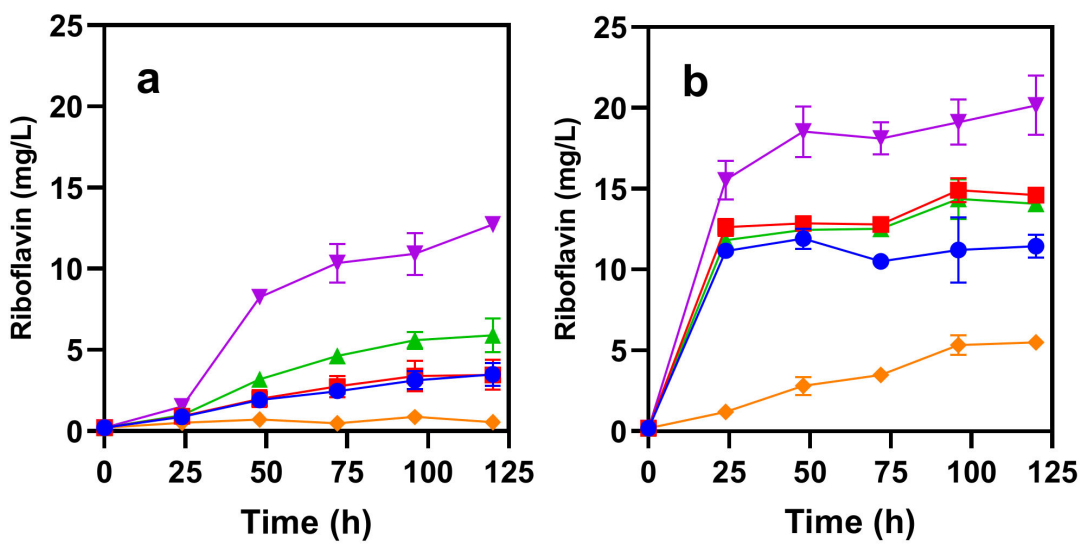

$\bullet$ IST $495 \rightarrow$ IST $498 \rightarrow$ IST $507 \rightarrow$ IST $626 \rightarrow$ PYCC $2727^{\top}$

Figure 2. Riboflavin production by C. membranifaciens strains IST 495, IST498, IST 507, and IST 626 isolated in this study, and the type strain PYCC $2727^{\mathrm{T}}$. All strains were cultured in YNB (a), or YNB-Fe (b). All media contained $20 \mathrm{~g} / \mathrm{L}$ of glucose. Riboflavin production was determined during $120 \mathrm{~h}$ of growth at $30^{\circ} \mathrm{C}$ and orbital agitation $(250 \mathrm{rpm})$. Error bars represent the standard deviations of three independent measurements.

Based on the higher riboflavin production capacity of $C$. membranifaciens IST 626 , this strain was selected for further studies that included the determination of the effect of iron addition to YNB-Fe (Figure 3) and the optimization of growth medium conditions for riboflavin production (Figure 4). The supplementation of YNB-Fe with increasing concentrations of iron (III) chloride decreased riboflavin production by C. membranifaciens IST 626 in a dose-dependent manner (Figure 3). Among the conditions tested, the concentration of riboflavin produced and of remaining glucose was higher and biomass concentration was lower when C. membranifaciens IST 626 was cultured for $120 \mathrm{~h}$ in medium without iron. When increasing concentrations of iron (III) chloride were added to commercial YNB-Fe, a dose-dependent decrease in riboflavin concentration was observed after $120 \mathrm{~h}$ of growth. The concentration of cells and glucose was similar in all iron-(III)-chloride-supplemented media. The commercial medium YNB (containing $~ 1.2 \mu \mathrm{M}$ iron (III) chloride) was used as a control. This study demonstrates the impact of different concentrations of iron (III) chloride in the volumetric production of riboflavin and shows that, in the absence of iron, biomass production and glucose consumption are negatively affected due to iron limitation.

In the case of C. membranifaciens IST 626 , riboflavin overproduction $(>10 \mathrm{mg} / \mathrm{L})$ was observed when iron (III) chloride was added at concentrations below $1.0 \mu \mathrm{M}$. The link between iron metabolism and flavinogenesis has long been established [15] but, after 40 years of research, the molecular and physiological mechanisms underlying such a relationship 
in flavinogenic yeasts remain poorly understood. Under iron depletion, riboflavin has been suggested to play a role in the nonenzymatic reduction of insoluble $\mathrm{Fe}^{3+}$ to the more accessible soluble $\mathrm{Fe}^{2+}$ or to act as a cofactor for the activity of intra- and extracellular enzymes [12]. This mechanism is well documented in some bacterial species [41,42], but was not validated in flavinogenic yeasts [12]. Iron is a vital micronutrient that is essential for multiple biological processes, including respiration, given that respiratory complexes contain heme and Fe-S clusters whose synthesis depends on iron availability [43]. In $S$. cerevisiae, at concentrations bellow $1 \mu \mathrm{M}$ Fe, the cell faces iron deficiency and prioritizes the utilization of this micronutrient, meaning that most of the available iron goes to the mitochondria, where it is assembled into Fe-S clusters and heme centers, as well as prosthetic groups that are critical for cellular metabolism [44]. Other cellular processes can be severely affected by iron starvation due to the decrease in the availability of iron-dependent metabolites, such as amino acid intermediates, heme, unsaturated fatty acids, and deoxyribonucleotides [45], which may lead to a deceleration or even abrogation of several metabolic processes, for instance, sugar metabolization. The higher glucose concentration present in the medium without iron after $120 \mathrm{~h}$ of cultivation (Figure 3) might be the result of the deceleration of growth and sugar metabolism.

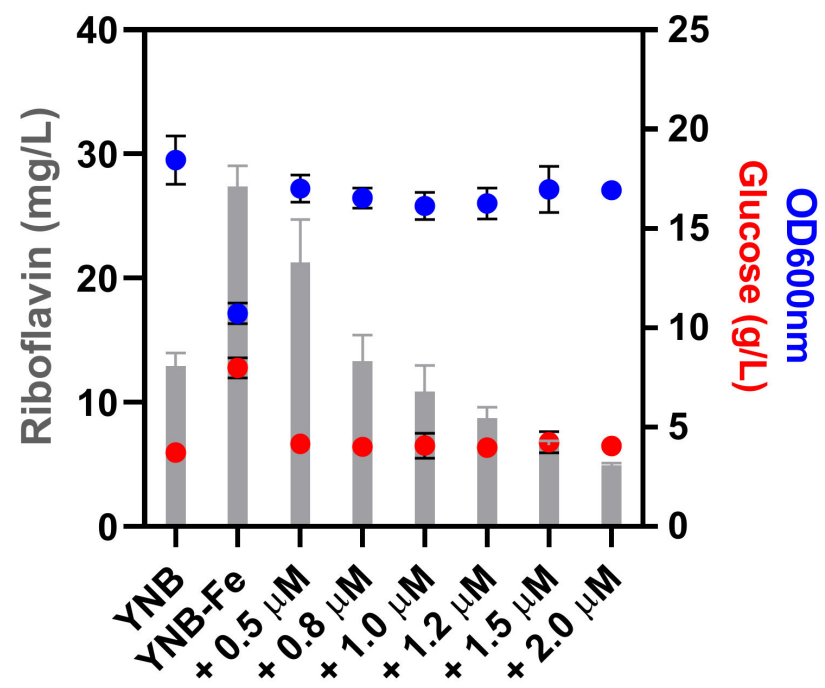

Figure 3. Riboflavin (bars), biomass $\left(\mathrm{OD}_{600 \mathrm{~nm}}\right)$ (blue circles), and glucose (red circles) concentrations determined after $120 \mathrm{~h}$ of cultivation of $C$. membranifaciens IST 626 in media containing different iron concentrations. C. membranifaciens IST 626 was grown under standardized conditions in YNB and in YNB-Fe to which increasing concentrations of iron (III) chloride $(+0.5 \mu \mathrm{M},+0.8 \mu \mathrm{M},+1.0 \mu \mathrm{M},+1.2 \mu \mathrm{M}$, $+1.5 \mu \mathrm{M},+2.0 \mu \mathrm{M})$ were added. All media contained $20 \mathrm{~g} / \mathrm{L}$ of glucose. Riboflavin and glucose concentrations, and $\mathrm{OD}_{600 \mathrm{~nm}}$ were determined after $120 \mathrm{~h}$ of growth at $30{ }^{\circ} \mathrm{C}$ and orbital agitation (250 rpm). Error bars represent the standard deviations of three independent measurements.

Comparison of riboflavin production by C. membranifaciens IST 626 cells cultured in either glucose (Figure 4a) or xylose (Figure $4 \mathrm{~b}$ ) showed that the volumetric production of this vitamin was higher when xylose was the available sugar, reaching approximately $33 \mathrm{mg} / \mathrm{L}$ after $120 \mathrm{~h}$ of cultivation. Ethanol was produced by C. membranifaciens IST 626 when glucose was the available sugar (Figure $4 b, c, e$ ). The percentage of glucose diverted to either alcoholic fermentation or respiration in this species has not been studied but, as in S. cerevisiae, C. membranifaciens was also able to produce ethanol from glucose under aerobic conditions. In contrast, xylose was assimilated but not fermented by this species (Figure $4 b, d, f)$. 


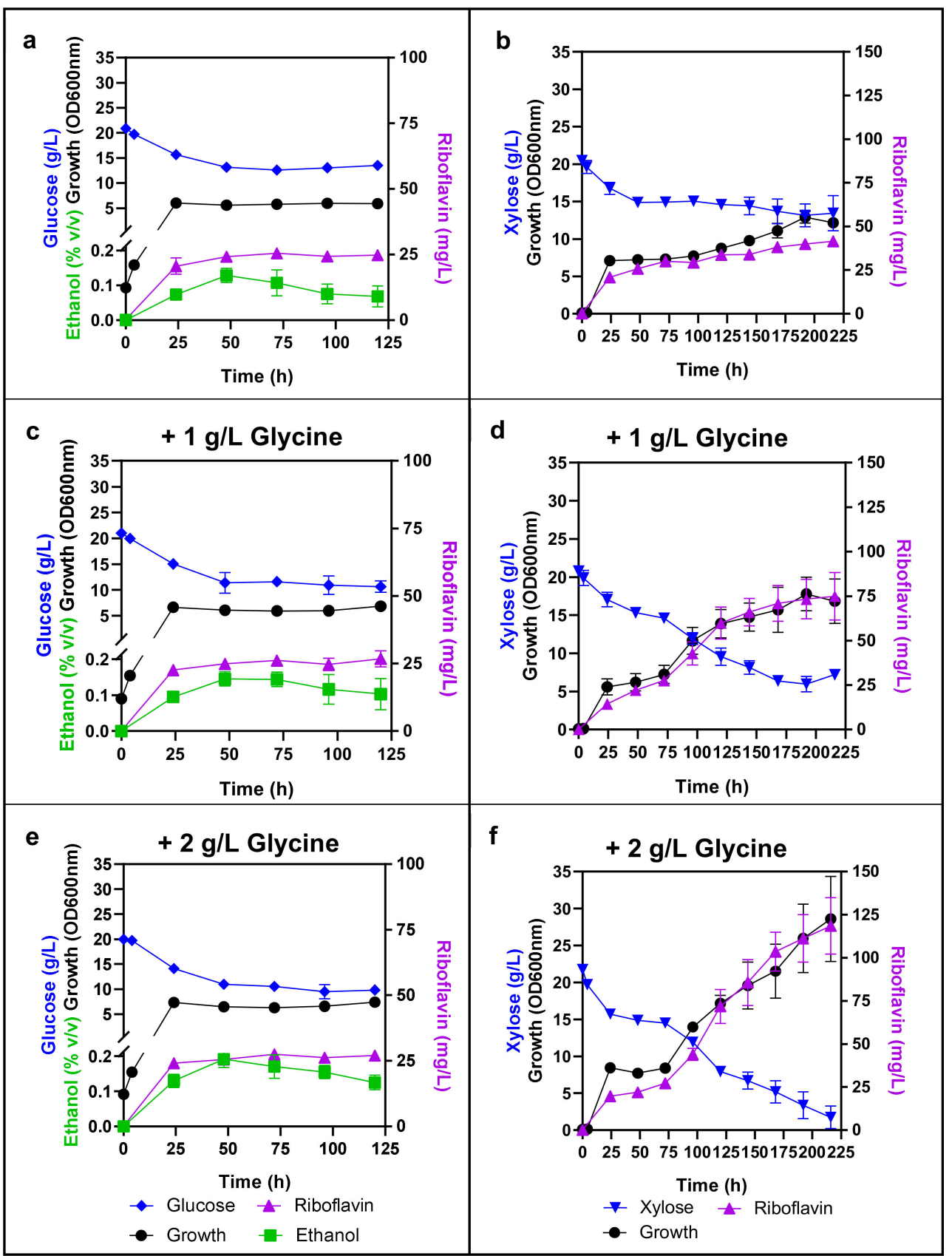

Figure 4. Glycine supplementation of the growth medium increases riboflavin volumetric production by C. membranifaciens IST 626 when xylose is the available carbon source. This strain was cultured in YNB-Fe supplemented with $20 \mathrm{~g} / \mathrm{L}$ of either glucose $(\mathbf{a}, \mathbf{c}, \mathbf{e})$ or xylose $(\mathbf{b}, \mathbf{d}, \mathbf{f})$, without glycine $(\mathbf{a}, \mathbf{b})$, with $1 \mathrm{~g} / \mathrm{L}$ of glycine $(\mathbf{c}, \mathbf{d})$, or $2 \mathrm{~g} / \mathrm{L}$ of glycine $(\mathbf{e}, \mathbf{f})$. Samples were collected every $24 \mathrm{~h}$ in cells grown at $30{ }^{\circ} \mathrm{C}$ with an orbital agitation (250 rpm). Cultivations in media containing glucose were performed for $120 \mathrm{~h}$ and cultivations in media containing xylose were extended to $216 \mathrm{~h}$. Results are the mean of three independent experiments.

Based on the reported increase in riboflavin production by C. flareri (C. famata) and by $A$. gossipy when cultivated in media supplemented with glycine [21,46], the effect of glycine supplementation in YNB-Fe media containing either glucose or xylose was also assessed (Figure 4). Although glucose consumption and cell growth were slightly favored by glycine supplementation during the first two days of fermentation, riboflavin production by C. membranifaciens IST 626 was not enhanced by glycine addition to glucose YNB-Fe media (Figure $4 \mathrm{a}, \mathrm{c}, \mathrm{e}$ ) and, for this reason, growth curves in these media were only followed 
for $120 \mathrm{~h}$. Differently, riboflavin production was stimulated by the addition of glycine to the culture medium containing xylose (Figure $4 \mathrm{~b}, \mathrm{~d}, \mathrm{f}$ ). Riboflavin concentration reached approximately $120 \mathrm{mg} / \mathrm{L}$ and xylose was almost fully consumed after $216 \mathrm{~h}$ of cultivation in medium supplemented with $2 \mathrm{~g} / \mathrm{L}$ glycine (Figure $4 \mathrm{f}$ ). The increase in riboflavin production in glycine-containing media correlates with the increase in yeast biomass, indicating that glycine was essential for the full catabolism of the xylose present. In the flavinogenic yeast C. flareri, the mechanisms underlying the enhancement of riboflavin production by glycine were not clarified [21]. Nevertheless, it is known that, in S. cerevisiae, glycine participates in multiple biological processes. They include, for example, the biosynthesis of purines, glyoxylate [47], of glutathione [48], and of serine by the glycine decarboxylase multienzyme complex that plays a critical role in connecting the metabolism of one-, two-, and threecarbon compounds in different metabolic pathways [49]. The positive impact of amino acids on the catabolism of other carbon sources by a different nonconventional yeast was previously demonstrated [50]. Although our results do not elucidate how glycine relates to catabolization of xylose and, consequently, increased biomass and riboflavin production, overall, they indicate that the production of this vitamin by C. membranifaciens remarkably increased upon optimization of the growth medium with xylose and glycine and that this strain can be further exploited to produce this vitamin.

Having in mind the future exploration of this strain for riboflavin production, it was considered of interest to obtain the first genome sequence for the species C. membranifaciens and the best riboflavin-producing strain IST 626 and provide its assembly and annotation. This is expected to contribute to enlightening the molecular mechanisms underlying riboflavin biosynthesis and the ability of this species to assimilate a wide variety of carbon sources.

\subsection{General features of Candida membranifaciens IST 626 Genome}

The genome sequence of $C$. membranifaciens IST 626 was obtained by paired-end Illumina sequencing. A total of 17 million reads were acquired and assembled into 56 scaffolds $(\geq 2000 \mathrm{bp})$, resulting in an overall sequence coverage of $224 x$. A summary of genome assembly statistics is presented in Table 1.

Table 1. Genome assembly statistics of C. membranifaciens IST 626.

\begin{tabular}{cc}
\hline Feature & \\
\hline Total reads & $17,196,026$ \\
No. of scaffolds $(\geq 2000 \mathrm{bp})$ & 56 \\
Coverage & $224 \mathrm{x}$ \\
N50 (bp) & $667,103 \mathrm{bp}$ \\
L50 & 7 \\
Maximum contig length (bp) & $1,053,043 \mathrm{bp}$ \\
Minimum contig length (bp) & $2057 \mathrm{bp}$ \\
Assembly size (bp) & $11,508,125 \mathrm{bp}$ \\
GC content (\%) & $32.15 \%$ \\
\hline
\end{tabular}

The sum of all scaffold sizes is $11,508,125 \mathrm{bp}$. The predicted GC content is $32.15 \%$. This value is below the minimum value on the range of the GC content of other species from the Candida/Yamadazyma clade (GC content varies from 33.5 to 53.9\%) [51-53]. A total of 5619 genes were predicted to be encoded in the genome of $C$. membranifaciens IST 626 . Protein functions were assigned to $61 \%$ (3446 genes) of the predicted genes according to the eukaryotic orthologous groups of proteins (KOG) classification [54] (Figure 5). Among them, 1165 genes were assigned to "Cellular processes and signaling", 980 genes to "Information storage and processing", and 1301 genes to "Metabolism" major categories. In this latter category, the most dominant functions are "Amino acid transport and metabolism" (243 genes), "Energy production and conversion" (210 genes), "Carbohydrate transport and metabolism" (174 genes), and "Lipid transport and metabolism" (172 genes). A to- 
tal of 893 genes (16\% of the assigned genes) were included in the "Poorly characterized functions" category, which includes the categories "Function unknown" and "General function prediction only". The number of genes assigned to each function is detailed in Supplementary file 1, where the number of genes assigned to other species related to $C$. membranifaciens is also included.

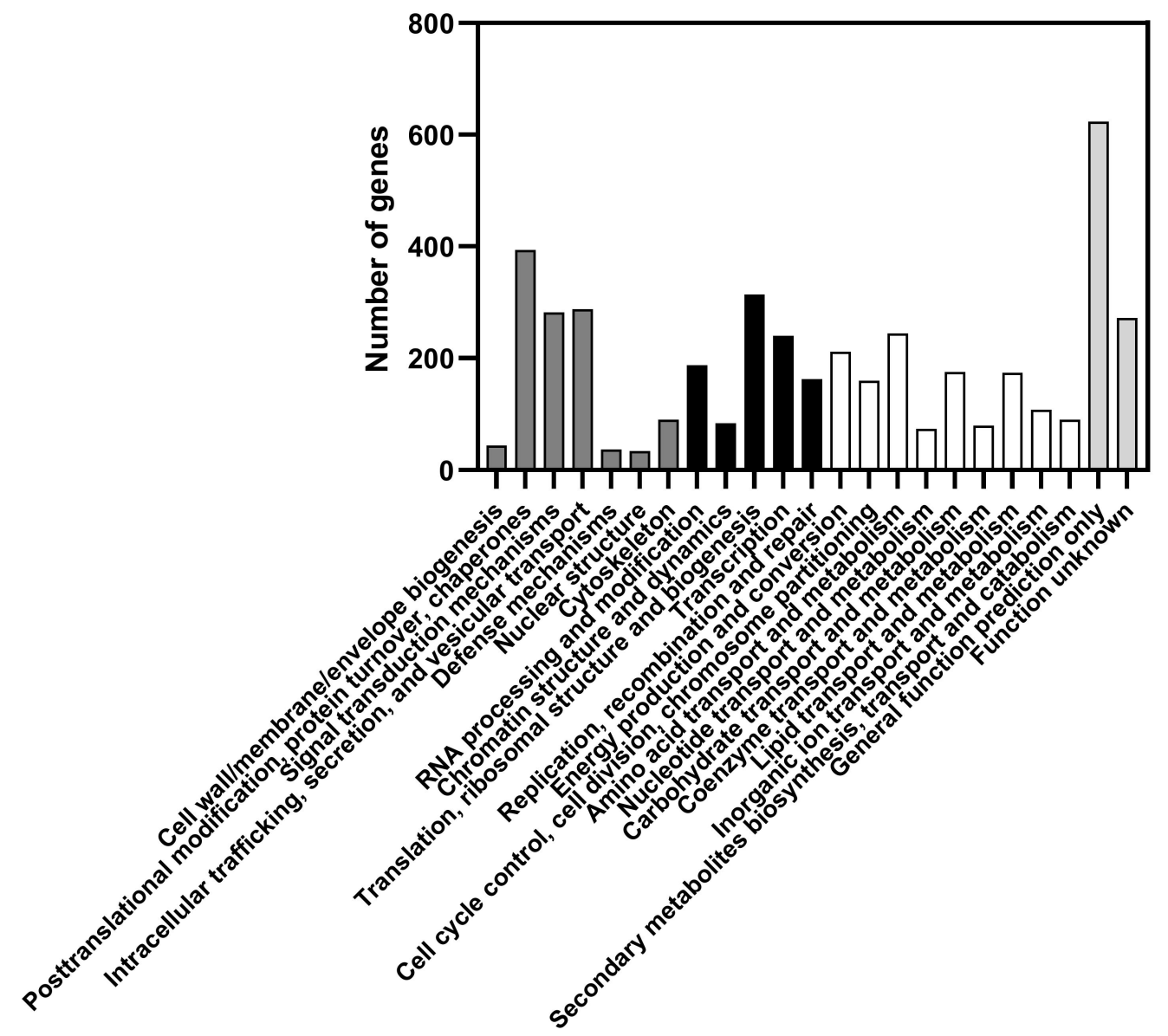

Figure 5. Number of predicted genes assigned to a function based on the eukaryotic orthologous groups of proteins (KOG) classification. Represented is the distribution of predicted genes according to their putative function within the major categories "Cellular processes and signaling" (dark grey), "Information storage and processing" (black), "Metabolism" (white), and "Poorly characterized functions" (light grey).

\subsection{Genomic Information and Corresponding Metabolic Traits}

\subsubsection{Proteins Associated with Riboflavin Production and Transport}

Riboflavin biosynthesis comprises a total of seven enzymatic reactions controlled by six $R I B$ genes and an unknown gene that codes for an enzyme catalyzing the dephosphorylation of 5-amino-6-ribitylamino-2,4(1H,3H) pyrimidinedione 5'-phosphate (ARPP). The phosphatase responsible for this reaction in Arabidopsis thaliana was recently described [55], but its homolog in yeast remains unknown. The genome of C. membranifaciens IST 626 contains the homologs of RIB1, RIB2, RIB3, RIB4, RIB5, and RIB7 (Table 2), as well as the genes involved in the synthesis of flavin mononucleotide (FMN) (FMN1) and flavin adenine dinucleotide (FAD) (FAD1), which are essential cofactors for the majority of flavoproteins / flavocoenzymes in different organisms [7,8]. To search for the missing phosphatase in the riboflavin biosynthetic pathway in C. membranifaciens IST 626 genome, the protein sequence of $A$. thaliana 5-amino-6-(5-phospho-D-ribitylamino)uracil phosphatase (AtPyrP2) [55] was used as a query in JGI's MycoCosm Blast search tool. Two candidate proteins for the 
dephosphorylation of ARPP were identified (Table 2), which belong to the group of HAD hydrolyses, as in A. thaliana.

Table 2. Homologs of flavin biosynthetic genes in C. membranifaciens IST 626 and putative transcription factors (TFs) controlling the target gene expression considering the identified transcription factor binding sites (TFBSs) found in the promoter regions of those genes.

\begin{tabular}{|c|c|c|c|c|}
\hline $\begin{array}{l}\text { Protein } \\
\text { ID }\end{array}$ & $\begin{array}{l}\text { Homolog in } \\
\text { C. albicans }\end{array}$ & $\begin{array}{l}\text { Amino Acid } \\
\text { Identity (\%) }\end{array}$ & Molecular Function (*) & $\begin{array}{l}\text { Putative TFs Based on } \\
\text { Predicted Binding Sites }\end{array}$ \\
\hline 30281 & RIB1 & $74 \%$ & GTP cyclohydrolase II & $\begin{array}{c}\text { Efg1, Tye7, Brg1, Hmo1, } \\
\text { Nrg1, Rap1, } \\
\text { Hap43/Hap5, Upc2, } \\
\text { Wor3, Mrr1, Ace2, Hap5, } \\
\text { Rtg1, Rtg3, Zcf29 }\end{array}$ \\
\hline 15396 & RIB2 & $67 \%$ & Pseudouridine synthase & $\begin{array}{l}\text { Efg1, Tye7, Ndt80, Skn7 } \\
\qquad(* *)\end{array}$ \\
\hline 15025 & RIB3 & $77 \%$ & $\begin{array}{l}\text { 3,4-dihydroxy-2-butanone- } \\
\text { 4-phosphate synthase } \\
\text { (DHBP synthase) }\end{array}$ & $\begin{array}{c}\text { Efg1, Brg1, Nrg1, Rim101, } \\
\text { Hap43/Hap5, Wor3, } \\
\text { Mrr1, Hap5, Rgt1, Rtg3, } \\
\text { Zcf29, Skn7 }\end{array}$ \\
\hline 34729 & RIB4 & $77 \%$ & $\begin{array}{l}\text { Lumazine synthase (6,7- } \\
\text { dimethyl-8-ribityllumazine } \\
\text { synthase synthase) }\end{array}$ & $\begin{array}{l}\text { Efg1, Tye7, Ndt80, Nrg1, } \\
\text { Upc2, Wor3, Mrr1, Rgt1, } \\
\text { Ace2, Zcf29 }\end{array}$ \\
\hline 13130 & RIB5 & $69 \%$ & Riboflavin synthase & $\begin{array}{c}\text { Efg1, Brg1, Nrg1, Rap1, } \\
\text { Hap43/Hap5, Mrr1, } \\
\text { Rgt1, Ace2, Hap5, Zcf29, } \\
\text { Skn7, Cta8 }\end{array}$ \\
\hline 18055 & RIB7 & $53 \%$ & $\begin{array}{l}\text { 5-amino-6-(5- } \\
\text { phosphoribosylamino)uracil } \\
\text { reductase }\end{array}$ & $\underset{(* *)}{\operatorname{Brg} 1, \text { Hap43/Hap5, Mrr1 }}$ \\
\hline 25813 & FMN1 & $50 \%$ & Riboflavin kinase & $\begin{array}{c}\text { Upc2, Wor3, Mrr1, Hap5, } \\
\text { Zcf29 (**) }\end{array}$ \\
\hline 24533 & FAD1 & $51 \%$ & $\begin{array}{c}\text { Flavin adenine } \\
\text { dinucleotide (FAD) } \\
\text { synthetase }\end{array}$ & Nrg1, Tbf1, Wor3 $\left.{ }^{* *}\right)$ \\
\hline $\begin{array}{c}34484 \\
(* * *)\end{array}$ & RHR2 & $84 \%$ & $\begin{array}{l}\text { Predicted } \\
\text { haloacid-halidohydrolase }\end{array}$ & $\begin{array}{c}\text { Efg1, Tye7, Ndt80, Brg1, } \\
\text { Nrg1, Rap1, Rim101, } \\
\text { Hap43/Hap5, Wor1, } \\
\text { Mrr1, Mig1, Rgt1, Zcf29, } \\
\text { Skn7 }\end{array}$ \\
\hline $\begin{array}{c}23627 \\
(* * *)\end{array}$ & DOG1 & $26 \%$ & $\begin{array}{c}\text { Predicted } \\
\text { haloacid-halidohydrolase }\end{array}$ & Brg1, Mrr1, Hap5 (**) \\
\hline
\end{tabular}

$\left({ }^{*}\right)$ Molecular function was retrieved from Candida Genome Database [56]; $\left(^{* *}\right)$ TFBSs predicted in promoter sequences smaller than $160 \mathrm{bp}$. $\left.{ }^{* * *}\right)$ Candidate genes for the dephosphorylation of ARPP in riboflavin biosynthetic pathway.

The overexpression of riboflavin biosynthetic genes in flavinogenic yeasts leads to the increase in riboflavin production in different species (reviewed in [57]). For instance, in C. famata the overexpression of the riboflavin biosynthetic genes RIB1 and RIB7 and of the transcriptional activator SEF1 remarkably increased riboflavin production [58]. This transcription factor is essential for riboflavin production in C. famata and P. guilliermondii [12,59] and plays a role in iron homeostasis in the flavinogenic yeast C. albicans [60]. In this later species, Sef1 directly binds to the promoter of RIB1 under iron-limiting conditions [61]. This transcription factor, together with Hap43 and Sfu1 are key regulators in the transcriptional control of iron-responsive genes [61,62]. Under iron-limiting conditions, Hap43 and ironuptake genes are activated by Sef1 [61]. In contrast, under iron repletion conditions, SEF1 and iron-uptake genes are repressed by Sfu1 (GATA factor) that, in turn, is repressed by Hap43 under low concentrations of iron [61]. Moreover, Hap43 also regulates the expression of the core HAP complex genes HAP5, HAP32, and HAP2, thus being considered a master regulator of iron homeostasis [62]. Remarkably, Hap43 was found to be involved in the positive regulation of RIB4 (orf19.410.3) in C. albicans under iron depletion conditions [62]. 
Homologs of those transcription factors were identified in the genome sequence of $C$. membranifaciens IST 626 (Table 3).

Table 3. Homologs of genes involved in iron homeostasis and regulation identified in the genome sequence of $C$. membranifaciens IST 626.

\begin{tabular}{|c|c|c|c|c|}
\hline & $\begin{array}{l}\text { Protein } \\
\text { ID }\end{array}$ & $\begin{array}{c}\text { Homolog in } C . \\
\text { albicans }\end{array}$ & $\begin{array}{l}\text { Amino Acid } \\
\text { Identity (\%) }\end{array}$ & Molecular Function (*) \\
\hline \multirow[t]{5}{*}{$\begin{array}{l}\text { Regulation of } \\
\text { iron metabolism }\end{array}$} & 24521 & Sfu1 & $62 \%$ & $\begin{array}{l}\text { Zinc finger, GATA-type } \\
\text { transcription factor }\end{array}$ \\
\hline & 23730 & Hap43 & $52 \%$ & Basic-leucine zipper domain \\
\hline & 13665 & Sef1 & $67 \%$ & $\begin{array}{l}\mathrm{Zn}(2)-\mathrm{C} 6 \text { fungal-type } \\
\text { DNA-binding domain }\end{array}$ \\
\hline & 29747 & Aft2 & $41 \%$ & $\begin{array}{l}\text { Hypothetical transcription } \\
\text { factor }\end{array}$ \\
\hline & 18845 & Hap5 & $79 \%$ & $\begin{array}{l}\text { Histone-like transcription } \\
\text { factor }\end{array}$ \\
\hline \multirow[t]{13}{*}{$\begin{array}{l}\text { High-affinity } \\
\text { reductive system }\end{array}$} & 16867 & Fre10 & $45 \%$ & Ferric reductase $(* *)$ \\
\hline & 34201 & $\mathrm{Cfl} 2$ & $43 \%$ & Ferric reductase $(* *)$ \\
\hline & 10230 & Fre9 & $51 \%$ & Ferric reductase $(* *)$ \\
\hline & 23390 & Cfl2 & $24 \%$ & Ferric reductase $\left({ }^{* *}\right)$ \\
\hline & 14512 & Frp2 & $39 \%$ & Ferric reductase $\left({ }^{* *}\right)$ \\
\hline & 31983 & orf19.867 & $26 \%$ & Ferric reductase $\left({ }^{* *}\right)$ \\
\hline & 20041 & orf19.4843 & $50 \%$ & Ferric reductase \\
\hline & 34362 & Fet31 & $69 \%$ & Multicopper oxidase \\
\hline & 12903 & Fet33 & $58 \%$ & Multicopper oxidase \\
\hline & 29609 & Ftr1 & $74 \%$ & High-affinity iron transporter \\
\hline & 35518 & Ccc2 & $49 \%$ & $\begin{array}{c}\mathrm{Cu} 2+\text { transporter P-type } \\
\text { ATPase }\end{array}$ \\
\hline & 34023 & Crp1 & $55 \%$ & $\begin{array}{c}\mathrm{Cu} 2+\text { transporter P-type } \\
\text { ATPase }\end{array}$ \\
\hline & 14754 & Atx1 & $60 \%$ & Copper metallochaperone \\
\hline \multirow[t]{3}{*}{$\begin{array}{c}\text { Siderophore } \\
\text { uptake system }\end{array}$} & 14012 & Sit1 & $58 \%$ & Siderophore iron transporter \\
\hline & 28384 & Sit1 & $45 \%$ & Siderophore iron transporter \\
\hline & 29780 & Sit1 & $26 \%$ & Siderophore iron transporter \\
\hline \multirow[t]{3}{*}{$\begin{array}{c}\text { Heme or } \\
\text { hemoglobin } \\
\text { utilization } \\
\text { system }\end{array}$} & 28257 & $\operatorname{Hmx} 1$ & $64 \%$ & Heme oxygenase \\
\hline & 25343 & Pga10 (Rbt51) & $52 \%$ & $\begin{array}{l}\text { Glycosylphosphatidylinositol } \\
\text { (GPI)-modified cell wall } \\
\text { protein }\end{array}$ \\
\hline & 30576 & Pga7 & $57 \%$ & $\begin{array}{l}\text { Glycosylphosphatidylinositol } \\
\text { (GPI)-modified cell wall } \\
\text { protein }\end{array}$ \\
\hline
\end{tabular}


Table 3. Cont.

\begin{tabular}{|c|c|c|c|c|}
\hline & $\begin{array}{l}\text { Protein } \\
\text { ID }\end{array}$ & $\begin{array}{c}\text { Homolog in } C . \\
\text { albicans }\end{array}$ & $\begin{array}{l}\text { Amino Acid } \\
\text { Identity (\%) }\end{array}$ & Molecular Function (*) \\
\hline \multirow[t]{12}{*}{$\begin{array}{l}\text { Iron-sulfur } \\
\text { assembly }\end{array}$} & 13591 & Isu1 & $64 \%$ & Iron-sulfur cluster assembly \\
\hline & 17237 & $\begin{array}{c}\mathrm{Nfu2} \\
\text { (orf19.6283) }\end{array}$ & $75 \%$ & $\begin{array}{l}\text { Iron-sulfur cluster binding } \\
\text { activity }\end{array}$ \\
\hline & 28973 & $\begin{array}{c}\text { Nfu1 } \\
\text { (orf19.2067) }\end{array}$ & $70 \%$ & Iron-sulfur cluster assembly \\
\hline & 26437 & Isa1 & $52 \%$ & Iron-sulfur cluster assembly \\
\hline & 32180 & Isa2 & $56 \%$ & Iron-sulfur cluster assembly \\
\hline & 24028 & Dre2 & $39 \%$ & Iron-sulfur cluster assembly \\
\hline & 25680 & Yfh1 & $46 \%$ & $\begin{array}{l}\text { Mitochondrial matrix protein } \\
\text { frataxin, involved in } \mathrm{Fe} / \mathrm{S} \\
\text { protein biosynthesis }\end{array}$ \\
\hline & 14713 & Atm1 & $72 \%$ & $\begin{array}{c}\text { mitochondrial } \mathrm{ABC} \\
\text { transporter; transport of } \\
\text { iron-sulfur cluster precursors }\end{array}$ \\
\hline & 18779 & Nar1 & $54 \%$ & $\begin{array}{l}\text { Putative cytosolic iron-sulfur } \\
\text { (FeS) protein assembly } \\
\text { machinery protein }\end{array}$ \\
\hline & 28349 & Nbp35 & $65 \%$ & $\begin{array}{l}\text { ATPase activity, iron-sulfur } \\
\text { cluster binding activity and } \\
\text { role in iron-sulfur cluster } \\
\text { assembly }\end{array}$ \\
\hline & 15021 & Nbp35 & $84 \%$ & $\begin{array}{l}\text { ATPase activity, iron-sulfur } \\
\text { cluster binding activity and } \\
\text { role in iron-sulfur cluster } \\
\text { assembly }\end{array}$ \\
\hline & 12204 & $\mathrm{Nbp} 35$ & $77 \%$ & $\begin{array}{l}\text { ATPase activity, iron-sulfur } \\
\text { cluster binding activity and } \\
\text { role in iron-sulfur cluster } \\
\text { assembly }\end{array}$ \\
\hline
\end{tabular}

$\left({ }^{*}\right)$ Molecular function retrieved from Candida Genome Database [56]; $\left.{ }^{* *}\right)$ Contains a FAD-binding domain.

Given the taxonomic proximity between C. albicans and C. membranifaciens, we used the YEASTRACT+ portal [35], a valuable tool that allows cross-species comparative genomics of transcription regulation in nonconventional yeasts [36], to search for putative transcription factor binding sites (TFBS) in the sequences upstream of the genes that code for riboflavin biosynthetic enzymes in C. membranifaciens, using as a query the TFBS predicted for TFs from C. albicans (Table 2). Remarkably, putative TFBSs for Hap43/Hap5 (CCAAT binding site) or Hap5 (CCATT binding site) were detected in the promoter sequences of several $C$. membranifaciens riboflavin biosynthetic genes and of the candidate genes for the dephosphorylation of ARPP in the riboflavin biosynthetic pathway (Table 2), but no TFBS for Sef1 was identified using this tool. This may indicate that the described TFBS for $C$. albicans Sef1 is distinct to that of $C$. membranifaciens. Nonetheless, the possible regulation of riboflavin biosynthetic genes by Hap43/Hap5 deserves attention and to be experimentally validated.

Riboflavin transport in and out of the cell is still poorly characterized in flavinogenic yeasts, but two riboflavin permeases and one riboflavin excretase were described in $P$. guilliermondii (reviewed in [63]). More recently, a riboflavin excretase Rfe1 from C. flareri was also identified based on homology with D. hansenii DEHA2C03784p [64]. Using the same homology approach, we identified a putative riboflavin excretase in the genome 
sequence of C. membranifaciens IST 626 (Table 4). Interestingly, based on the MCL clustering tool [65] at JGI MycoCosm portal, the annotated protein is not conserved among the species considered in the analysis, but is present in the flavinogenic yeasts C. albicans, C. tropicalis, $M$. guilliermondii, and D. hansenii. Concerning the import of the vitamin, in S. cerevisiae, an uptake system encoded by $\mathrm{MCH} 5$ that belongs to a family of monocarboxylate transporters was demonstrated to uptake riboflavin into the cell [66]. C. membranifaciens IST 626 genome includes a remarkable number of genes encoding proteins from this family, 12, compared with the six identified in C. albicans or the five in S. cerevisiae. Nevertheless, it is still unknown whether these transporters do have a role in riboflavin uptake in flavinogenic yeasts. The putative TFBS for Hap43/Hap5 were found in the promoter sequences from some of these C. membranifaciens encoding genes (Table 4).

\subsubsection{Proteins Associated with Iron Homeostasis and Regulation}

The homologs of genes involved in iron homeostasis and regulation, which also include genes encoding iron-dependent flavoproteins, were identified in C. membranifaciens IST 626 genome (Table 3). In S. cerevisiae and C. albicans, the main players of iron metabolism have been identified and characterized (reviewed in $[45,67])$. In C. albicans, this topic has attracted the attention of many researchers due to the extraordinary ability of this species to cope with the different concentrations of iron within the human host microenvironments [68]. In general, extracellular iron uptake in yeasts can occur through the high-affinity reductive iron uptake, which involves extracellular reduction of ferric iron by ferric reductases encoded by the FRE genes [69], and subsequent reoxidation to its ferric form by the Fet3 multicopper ferroxidase that makes a complex with the high-affinity iron transporter Ftr1 [70]. Seven ferric reductase encoding genes homologous to S. cerevisiae and C. albicans FRE genes were identified in the genome of $C$. membranifaciens IST 626, of which six contain an FAD-binding domain. Two FET3 homologs containing a copper-oxidase domain and one FTR1 homolog were also identified in the genome sequence of C. membranifaciens. In C. albicans, five putative multicopper oxidases have been identified, but only four possess the copper-oxidase domains (required for oxidase activity) [71]. Since copper is required for oxidase activity, the intracellular copper transporter Ccc2 is essential for the function of the reductive pathway and for high-affinity iron transport in both S. cerevisiae and C. albicans [72,73]. We found in the genome of C. membranifaciens two putative CCC2 homologs (Table 3). Remarkably, no FET4 homolog could be identified in C. membranifaciens IST 626 genome. In S. cerevisiae, Fet4 is responsible for the low-affinity uptake of ferrous iron [74], and, as found for C. membranifaciens, this transporter is absent from C. albicans genome [36].

The nonreductive iron import machinery in S. cerevisiae includes three cell wall mannoproteins (Fit1-Fit3) involved in the retention of siderophore-iron in the cell wall, and four iron-xenosiderophore-specific transporters (Arn1-Arn4). C. albicans holds dedicated uptake systems for ferrichrome siderophores (via Sit1/Arn1) and ferrioxamine siderophores (reductive iron uptake-Ftr1-dependent), whereas, in S. cerevisiae, Sit1 can facilitate the uptake of ferrioxamines, as well as ferrichrome-type siderophores [75]. In the C. membranifaciens genome sequence, as in C. albicans, no Fit1-Fit3 homologs were identified, but three Arn1/Sit1 homologs were detected, while C. albicans has only one Arn1/Sit1 in its genome (Table 3).

Yeasts also have the ability to utilize heme or hemoglobin as an iron source, a critical process for yeast survival and virulence previously characterized in S. cerevisiae and C. albicans [76]. In C. albicans, the uptake of hemoglobin is mediated by a family of specific hemoglobin receptors in the cell surface encoded by RBT5, RBT51, WAP1/CSA1, CSA2, and $P G A 7$ genes [77]. In S. cerevisiae, this family of hemoglobin transporters is absent, consistent with the, in general, nonvirulent nature of this species. After internalization of hemoglobin inside vacuoles, this molecule is hydrolyzed or denatured to release the heme group that can subsequently be oxidized by the heme oxygenase Hmx1 [76]. As in C. albicans and S. cerevisiae, C. membranifaciens includes in its genome sequence the gene encoding the 
heme oxygenase Hmx1, as well as the C. albicans homologs for hemoglobin receptors Pga10 (Rbt51) and Pga7 (Table 3).

Table 4. Candidates for riboflavin transport across $C$. membranifaciens plasma membrane and putative transcription factors controlling the target gene expression considering the identified TFBSs found in the promoter regions of those genes.

\begin{tabular}{|c|c|c|c|c|}
\hline $\begin{array}{l}\text { Protein } \\
\text { ID }\end{array}$ & $\begin{array}{l}\text { Homolog in } \\
\text { C. albicans }\end{array}$ & $\begin{array}{l}\text { Amino Acid } \\
\text { Identity (\%) }\end{array}$ & Molecular Function $(*)$ & $\begin{array}{l}\text { Putative TFs Based on } \\
\text { Predicted Binding Sites }\end{array}$ \\
\hline 17681 & orf19.3120 & $56 \%$ & $\begin{array}{c}\text { Riboflavin excretase. } \\
\text { ATP-binding cassette ABC } \\
\text { transporter. }\end{array}$ & $\begin{array}{c}\text { Efg1, Tye7, Rap1, Rim101, } \\
\text { Cph2, Hap43/Hap5, Mrr1, } \\
\text { Ace2, Hap5, Zcf29, Skn7, } \\
\text { Cta8, Cph2 }\end{array}$ \\
\hline 5199 & orf19.6263 & $55 \%$ & $\begin{array}{l}\text { Carbohydrate transport } \\
\text { and metabolism I } \\
\text { Monocarboxylate } \\
\text { transporter }\end{array}$ & $\begin{array}{c}\text { Efg1/Tye7, Ndt80, Wbr3, } \\
\text { Mrr1, Rgt1, Hap5, Zcf29, } \\
\text { Cta8, Cph2 }\end{array}$ \\
\hline 31581 & orf19.6263 & $34 \%$ & $\begin{array}{c}\text { Carbohydrate transport } \\
\text { and metabolism I } \\
\text { Monocarboxylate } \\
\text { transporter }\end{array}$ & $\begin{array}{c}\text { Tec1, Efg1/Tye7, Efg1, Brg1, } \\
\text { Nrg1, Rap1, Hsm1/Cph2, } \\
\text { Hap43/Hap5, Wor3, Mrr1, } \\
\text { Mig1, Hap5, Rgt1/Rgt3, } \\
\text { Zcf29, Cta8, Cph2 }\end{array}$ \\
\hline 31756 & orf19.5720 & $52 \%$ & $\begin{array}{c}\text { Carbohydrate transport } \\
\text { and metabolism I } \\
\text { Monocarboxylate } \\
\text { transporter }\end{array}$ & $\begin{array}{l}\text { Nrg1, Wor2, Hap5, Cta8, } \\
\text { Cph2 }\end{array}$ \\
\hline 31951 & orf19.6263 & $23 \%$ & $\begin{array}{c}\text { Carbohydrate transport } \\
\text { and metabolism I } \\
\text { Monocarboxylate } \\
\text { transporter }\end{array}$ & $\begin{array}{l}\text { Efg1, Efg1/Tye7, Rap1, Mrr1, } \\
\text { Skn7, Cta8, Cph2 }\end{array}$ \\
\hline 34553 & orf19.5720 & $48 \%$ & $\begin{array}{c}\text { Carbohydrate transport } \\
\text { and metabolism I } \\
\text { Monocarboxylate } \\
\text { transporter }\end{array}$ & $\begin{array}{c}\text { Tec1, Efg1, Ndt80, Brg1, Rap1, } \\
\text { Hap43/Hap5, Wor2, Mrr1, } \\
\text { Zcf29, Skn7, Cta8, Cph2 }\end{array}$ \\
\hline 34676 & orf19.2751 & $44 \%$ & $\begin{array}{c}\text { Carbohydrate transport } \\
\text { and metabolism I } \\
\text { Monocarboxylate } \\
\text { transporter }\end{array}$ & $\begin{array}{c}\text { Efg1/Tye7, Ndt80, Brg1, } \\
\text { Rap1, Tfb1, Rim101, } \\
\text { Hap43/Hap5, Upc2, Wor1, } \\
\text { Mrr1, Zcf29, Skn7, Cta8, } \\
\text { Cph2 }\end{array}$ \\
\hline 31444 & orf19.6263 & $53 \%$ & $\begin{array}{c}\text { Carbohydrate transport } \\
\text { and metabolism I } \\
\text { Monocarboxylate } \\
\text { transporter }\end{array}$ & $\begin{array}{c}\text { Tec1, Efg1/Tye7, Nrg1, Cbf1, } \\
\text { Upc2, Wor7, Mrr1, Mig1, } \\
\text { Hap5, Skn7, Cta8, Cph2 }\end{array}$ \\
\hline 33236 & orf19.4337 & $45 \%$ & $\begin{array}{c}\text { Carbohydrate transport } \\
\text { and metabolism I } \\
\text { Monocarboxylate } \\
\text { transporter }\end{array}$ & $\begin{array}{c}\text { Tec1, Brg1, Rap1, Wor2, Mrr1, } \\
\text { Hap5, Zcf29, Cta8, Skn7, } \\
\text { Cph2 }\end{array}$ \\
\hline 33235 & orf19.4337 & $46 \%$ & $\begin{array}{c}\text { Carbohydrate transport } \\
\text { and metabolism I } \\
\text { Monocarboxylate } \\
\text { transporter }\end{array}$ & $\begin{array}{c}\text { Brg1, rap1, Rim101, Wor3, } \\
\text { Mrr1, Rgt1, Ace2, Hap5, } \\
\text { Zcf29, Cta8, Cph2 }\end{array}$ \\
\hline 19539 & orf19.4337 & $27 \%$ & $\begin{array}{c}\text { Carbohydrate transport } \\
\text { and metabolism I } \\
\text { Monocarboxylate } \\
\text { transporter }\end{array}$ & $\begin{array}{c}\text { Efg1, Efg1/Tye7, Brg1, Nrg1, } \\
\text { Rap1, Hsm1/Cph2, } \\
\text { Hap43/Hap5, Upc2, Wor3, } \\
\text { Wor2, Mrr1, Mig1, Rgt1, } \\
\text { Ace2, Hap5, Zcf20, Skn7, } \\
\text { Cta8, Cph2 }\end{array}$ \\
\hline 15793 & orf19.6209 & $56 \%$ & $\begin{array}{c}\text { Carbohydrate transport } \\
\text { and metabolism I } \\
\text { Monocarboxylate } \\
\text { transporter }\end{array}$ & $\begin{array}{c}\text { Mac1, Tec1, Efg1, Efg1/Tye7, } \\
\text { Ndt80, Brg1, Rap1, } \\
\text { Hap43/Hap5, Wor3, Mrr1, } \\
\text { Mig1, Rgt1, Hap5, Zcf29, } \\
\text { Skn7, Cta8, Cph2 }\end{array}$ \\
\hline 26147 & orf19.6209 & $56 \%$ & $\begin{array}{l}\text { Carbohydrate transport } \\
\text { and metabolism I } \\
\text { Monocarboxylate } \\
\text { transporter }\end{array}$ & $\begin{array}{c}\text { Tec1, Efg1/Tye7, Efg1, Ndt80, } \\
\text { Brg1, Nrg1, Rap1, Tbf1, } \\
\text { Hsm1/cph2, Wor, Mrr1, Rgt1, } \\
\text { Hap5, Zcf29, Skn7, Cta8, } \\
\text { Cph2 }\end{array}$ \\
\hline
\end{tabular}

$\left({ }^{*}\right)$ Molecular function retrieved from Candida Genome Database [56]. 
In C. albicans, the activation of the iron regulon by Sef1 is co-ordinated with the biosynthesis of iron-sulfur clusters in the mitochondria [78]. Homologs of the genes involved in iron-sulfur cluster assembly were also identified in C. membranifaciens IST 626 genome (Table 3). Iron-sulfur clusters were proposed to play a role in the regulation of riboflavin biosynthesis and iron accumulation in the flavinogenic yeast $M$. guilliermondii, but the mechanisms underlying such an association remain unclear [79].

\subsubsection{Proteins Associated with Sugar Transport and Metabolism}

C. membranifaciens IST 626 can assimilate a wide variety of carbon sources that include hexoses (glucose and galactose), pentoses (xylose and arabinose), $\alpha$-glucosides (maltose, trehalose, melezitose), $\beta$-glucosides (cellobiose, salicin), $\beta$-fructosides (sucrose, inulin), and $\alpha$-galactosides (raffinose, melibiose), but is unable to assimilate lactose ( $\beta$-galactoside) (Supplementary file 2). The first steps for the assimilation of sugars involve their cellular uptake or extracellular hydrolysis, followed by uptake of smaller molecules. The genome of C. membranifaciens IST 626 holds a total of 45 proteins from the sugar porter family (TC 2.A.1.1) [34,80] (Table 5, Supplementary file 3). This remarkable number of putative sugar transporters includes maltose and general $\alpha$-glucoside transporters, involved in the transport of trehalose, maltose and/or melezitose, putative glucose/xylose facilitators and proton symporters, hexose transporters, glucose sensors, and transporters for other compounds, such as glycerol or quinate (Table 5, Supplementary file 3). Regardless of C. membranifaciens' inability to assimilate lactose, homologs of K. lactis galactose/lactose permease Lac12 [81] were found in its genome sequence. It is likely that these putative transporters are responsible for the uptake of galactose instead of lactose. Moreover, no $\beta$-galactosidase-encoding gene (KOG0496) was found in the genome of $C$. membranifaciens IST 626 (Supplementary files 1 and 4).

Table 5. Number of sugar transporters from the sugar porter family (TC 2.A.1.1) found in the genome sequence of C. membranifaciens IST 626. Transporters are organized into clusters according to the Transporter Classification (TC) system.

\begin{tabular}{cc}
\hline Annotation Description (Transporter Classification) & Number of Transporters \\
\hline Maltotriose/maltose:H+ symporter (2.A.1.1.10) & 1 \\
General $\alpha$-glucoside:H+ symporter (2.A.1.1.11) & 7 \\
Glucose/xylose: H+ symporter (2.A.1.1.51) & 2 \\
Xylose facilitator (2.A.1.1.40) & 3 \\
Glucose/xylose facilitator (2.A.1.1.67) & 3 \\
High affinity glucose transporter (2.A.1.1.39) & 4 \\
Lactose/Galactose:H+ symporter(2.A.1.1.9) & 2 \\
Glycerol:H+ symporter (2.A.1.1.38) & 6 \\
Glucose/Mannose/Galactose/Fructose:H+ symporter (2.A.1.43) & 3 \\
Quinate:H+ symporter (2.A.1.1.7) & 2 \\
Myoinositol:H+ symporter (2.A.1.1.8) & 6 \\
Hexose sensor (2.A.1.1.64) & 1 \\
Glucose Transporter/Sensor (2.A.1.1.68) & 1 \\
Sugar/Polyol transporter (2.A.1.1.69) & 2 \\
Total & 2 \\
\hline
\end{tabular}

Regarding the ability of C. membranifaciens IST 626 to assimilate sucrose and inulin, two genes encoding invertases (KOG0228) were identified in the genome of this strain (Supplementary files 1 and 4) (Protein IDs 17842 and 18031) and a melibiase-encoding gene was identified as well (Protein ID 18584, KOG2366), confirming this species' ability to assimilate melibiose (Supplementary files 1 and 4). C. membranifaciens is also able to assimilate cellobiose and salicin, and the presence of glycoside-hydrolase-encoding genes (Protein IDs 31127, 19784, 12153; KOG0626) confirmed the suggestion of $\beta$-glucosidase activity (Supplementary files 1 and 4 ). Other enzymes identified in this strain include $3 \alpha$ - 
amylases (Protein ID 11615, KOG3625; Protein IDs 18192 and 23493, KOG0471), consistent with its ability to assimilate soluble starch.

\section{Conclusions}

Valuable information regarding the isolation of $C$. membranifaciens strains from soil samples and the general ability of the species to produce riboflavin that, to date, was considered exclusive of $C$. membranifaciens subsp. flavinogenie W14-3 was provided. Among the C. membranifaciens isolates obtained and tested, strain C. membranifaciens IST 626 was selected as the best riboflavin producer and demonstrated that riboflavin production can be improved by culture medium optimization. Medium supplementation with glycine favored complete xylose metabolization, leading to higher biomass concentration and riboflavin volumetric production that reached approximately $120 \mathrm{mg} / \mathrm{L}$ after around $200 \mathrm{~h}$ of cultivation. C. membranifaciens IST 626 genome was sequenced and annotated, providing some indications on riboflavin biosynthesis and regulation and on the assimilation of different carbon sources. Putative transcription factor binding sites for Hap43 transcriptional regulator were found in the promoter regions of riboflavin biosynthetic genes' homologs (RIB1, RIB3, RIB5, RIB7, and FMN1), suggesting that Hap43 may have a role in the regulation of riboflavin biosynthesis under iron limitation. In future work, it would be interesting to examine the role of this transcription factor in the regulation of these and other genes, and compare the transcriptional profile of $C$. membranifaciens IST 626 and that of the type strain in different media. C. membranifaciens was found to hold a remarkable number of transporters for sugar/sugar-related compounds and metabolic enzymes, consistent with its capacity to use a wide variety of carbon sources, in particular, hexoses, pentoses, and inulin. These carbon sources are present in the hydrolysates from forest and agro-industrial residues, making this species a possible platform for riboflavin production from relevant feedstocks under a circular economy context. In conclusion, this work put forward the riboflavin overproducer C. membranifaciens and provides valuable molecular data to be used for the development of novel strains able to effectively use a wide range of raw materials in the production of added-value compounds.

Supplementary Materials: The following supporting information can be downloaded at: https: //www.mdpi.com/article/10.3390/jof8030254/s1, Supplementary file 1: Number of predicted genes assigned to a function based on the Eukaryotic orthologous groups of proteins (KOG) classification in Candida membranifaciens IST 626, Candida tenuis NRRL Y-1498, Candida tropicalis MYA3404, Meyerozyma guilliermondii ATCC 6260, and Candida albicans SC5314. Information was retrieved from MycoCosm portal of Joint Genome Institute; Supplementary file 2: Physiological characteristics of Candida membranifaciens IST 626; Supplementary file 3: Putative sugar transporters from the Sugar Porter family (2.A.1.1) found in the genome sequence of Candida membranifaciens IST 626. Transporters are organized into clusters according to the Transporter Classification (TC) system; Supplementary file 4: Glycoside hydrolases identified in the genome sequence of Candida membranifaciens IST 626 based on the Carbohydrate-Active Enzymes database (CAZy).

Author Contributions: Conceptualization, M.P. (Margarida Palma), I.S.-C.; Methodology, M.P. (Margarida Palma), I.V.G., I.S.-C.; Investigation, M.P. (Margarida Palma), S.M., M.P. (Mariana Pereira), É.V.; Validation, M.P. (Margarida Palma), M.P. (Mariana Pereira), S.M., É.V., I.V.G., I.S.-C.; Resources, I.S.-C., I.V.G.; Writing—original draft preparation, M.P. (Margarida Palma); Writing—review and editing, M.P. (Margarida Palma), S.M., I.V.G., I.S.-C.; Funding acquisition, I.S.-C. All authors have read and agreed to the published version of the manuscript.

Funding: This work was partially financially supported by the project Biodata.pt (01/SAICT/2016) funded by Programa Operacional Regional de Lisboa 2020 (LISBOA-01-0145-FEDER-022231). Funding from FCT in the scope of the project UIDB/04565/2020 and UIDP/04565/2020 of the Research Unit Institute for Bioengineering and Biosciences- $\mathrm{iBB}$ and the project LA/P/0140/2020 of the Associate Laboratory Institute for Health and Bioeconomy-i4HB is also acknowledged. MP holds a research contract (IST-ID/092/2018) funded by FCT. The work conducted by the U.S. Department of Energy Joint Genome Institute, a DOE Office of Science User Facility, is supported by the Office of Science of the U.S. Department of Energy under Contract No. DE-AC02-05CH11231. 
Institutional Review Board Statement: Not applicable.

Informed Consent Statement: Not applicable.

Data Availability Statement: The sequences from D1/D2 region of C. membranifaciens strains IST 495, IST 498, IST 507, and IST 626 were deposited in GenBank under the accession numbers MZ614941, MW003712, MW003715, and MW532700, respectively. The sequences from ITS region of C. membranifaciens strains IST 495, IST 498, IST 507, and IST 626 were deposited under the accession numbers MZ615411, MW003718, MW003721, and MW532702, respectively. The sequencing reads were deposited in Sequence Read Archive (SRA) under the accession number PRJNA777779 and the sequences obtained in the genome assembly were deposited in GenBank under the accession number JAKQXL000000000. The genome annotation is available in JGI fungal genome portal MycoCosm (https://mycocosm.jgi.doe.gov/Canmem1).

Conflicts of Interest: The authors declare no conflict of interest.

\section{References}

1. Lodder, J.; Kreger-van Rij, N.J.W. The Yeasts, a Taxonomic Study; North-Holland Publishing Co.: Amsterdam, The Netherlands, 1952.

2. Wickerham, L.J.; Burton, K.A. A Clarification of the Relationship of Candida guilliermondii to Other Yeasts by a Study of Their Mating Types. J. Bacteriol. 1954, 68, 594-597. [CrossRef]

3. Kurtzman, C.; Suzuki, M. Phylogenetic Analysis of Ascomycete Yeasts That Form Coenzyme Q-9 and the Proposal of the New Genera Babjeviella, Meyerozyma, Millerozyma, Priceomyces, and Scheffersomyces. Mycoscience 2010, 51, 2-14. [CrossRef]

4. Lachance, M.A.; Boekhout, T.; Scorzetti, G.; Fell, J.W.; Kurtzman, C.P. Candida Berkhout (1923). In The Yeasts. A Taxonomic Study; Kurtzman, C.P., Fell, J.W., Boekhout, T., Eds.; Elsevier: Amsterdam, The Netherlands, 2011; Volume 2, pp. 987-1278, ISBN 9780444521491.

5. Suh, S.O.; Nguyen, N.H.; Blackwell, M. Nine New Candida Species near C. membranifaciens Isolated from Insects. Mycol. Res. 2005, 109, 1045-1056. [CrossRef] [PubMed]

6. Wang, L.; Chi, Z.; Wang, X.; Ju, L.; Chi, Z.; Guo, N. Isolation and Characterization of Candida membranifaciens Subsp. flavinogenie W14-3, a Novel Riboflavin-Producing Marine Yeast. Microbiol. Res. 2008, 163, 255-266. [CrossRef] [PubMed]

7. Gudipati, V.; Koch, K.; Lienhart, W.D.; Macheroux, P. The Flavoproteome of the Yeast Saccharomyces cerevisiae. Biochim. Biophys. Acta Proteins Proteom. 2014, 1844, 535-544. [CrossRef] [PubMed]

8. Schall, P.; Marutschke, L.; Grimm, B. The Flavoproteome of the Model Plant Arabidopsis thaliana. Int. J. Mol. Sci. 2020, 21, 5371. [CrossRef]

9. Revuelta, J.L.; Ledesma-Amaro, R.; Jiménez, A. Industrial Production of Vitamin B2 by Microbial Fermentation. In Industrial Biotechnology of Vitamins, Biopigments, and Antioxidants; Vandamme, E.J., Revuelta, J.L., Eds.; Wiley-VCH: Weinheim, Germany, 2016; pp. 17-40.

10. Schwechheimer, S.K.; Park, E.Y.; Revuelta, J.L.; Becker, J.; Wittmann, C. Biotechnology of Riboflavin. Appl. Microbiol. Biotechnol. 2016, 100, 2107-2119. [CrossRef]

11. Averianova, L.A.; Balabanova, L.A.; Son, O.M.; Podvolotskaya, A.B.; Tekutyeva, L.A. Production of Vitamin B2 (Riboflavin) by Microorganisms: An Overview. Front. Bioeng. Biotechnol. 2020, 8, 570828. [CrossRef]

12. Abbas, C.A.; Sibirny, A.A. Genetic Control of Biosynthesis and Transport of Riboflavin and Flavin Nucleotides and Construction of Robust Biotechnological Producers. Microbiol. Mol. Biol. Rev. 2011, 75, 321-360. [CrossRef]

13. Nguyen, H.-V.; Gaillardin, C.; Neuveglise, C. Differentiation of Debaryomyces hansenii and Candida famata by RRNA Gene Intergenic Spacer Fingerprinting and Reassessment of Phylogenetic Relationships among D. Hansenii, C. famata, D. fabryi, C. flareri (=D. subglobosus) and D. prosopidis: Description of D. vietnamensis sp. nov. closely related to D. nepalensis. FEMS Yeast Res. 2009, 9, 641-662. [CrossRef]

14. Knight, S.A.B.; Lesuisse, E.; Stearman, R.; Klausner, R.D.; Dancis, A. Reductive Iron Uptake by Candida albicans: Role of Copper, Iron and the TUP1 Regulator. Microbiology 2002, 148, 29-40. [CrossRef] [PubMed]

15. Demain, A.L. Riboflavin Oversynthesis. Annu. Rev. Microbiol. 1972, 26, 369-388. [CrossRef] [PubMed]

16. Fitzpatrick, D.A.; Logue, M.E.; Stajich, J.E.; Butler, G. A Fungal Phylogeny Based on 42 Complete Genomes Derived from Supertree and Combined Gene Analysis. BMC Evol. Biol. 2006, 6, 99. [CrossRef]

17. Tanner, F.W.; Vojnovich, C.; Van Lanen, J.M. Riboflavin Production by Candida Species. Science 1945, 101, 180-181. [CrossRef]

18. Petrovska, Y.; Lyzak, O.; Dmytruk, K.; Sibirny, A. Effect of Gene SFU1 on Riboflavin Synthesis in Flavinogenic Yeast Candida famata. Cytol. Genet. 2020, 54, 408-412. [CrossRef]

19. Cecilia Mestre, M.; Rosa, C.A.; Safar, S.V.B.; Libkind, D.; Fontenla, S.B. Yeast Communities Associated with the Bulk-Soil, Rhizosphere and Ectomycorrhizosphere of a Nothofagus Pumilio Forest in Northwestern Patagonia, Argentina. FEMS Microbiol. Ecol. 2011, 78, 531-541. [CrossRef] [PubMed]

20. Lee, K.H.; Han, J.K.; Park, Y.H.; Park, J.H. Microorganisms and Process for the Production of Riboflavin by Fermentation. EP1426450A1, 9 June 2004. 
21. Heefner, D.L.; Weaver, C.A.; Yarus, M.J.; Burdzinski, L.A. Method for Producing Riboflavin with Candida famata. US5164303A, 17 November 1992.

22. Chi, Z.; Wang, L.; Ju, L.; Chi, Z. Optimisation of Riboflavin Production by the Marine Yeast Candida membranifaciens Subsp. flavinogenie W14-3 Using Response Surface Methodology. Ann. Microbiol. 2008, 58, 677-681. [CrossRef]

23. Dmytruk, K.V.; Yatsyshyn, V.Y.; Sybirna, N.O.; Fedorovych, D.V.; Sibirny, A.A. Metabolic Engineering and Classic Selection of the Yeast Candida famata (Candida flareri) for Construction of Strains with Enhanced Riboflavin Production. Metab. Eng. 2011, 13, 82-88. [CrossRef]

24. Zaky, A.S.; Greetham, D.; Louis, E.J.; Tucker, G.A.; Du, C. A New Isolation and Evaluation Method for Marine-Derived Yeast Spp. with Potential Applications in Industrial Biotechnology. J. Microbiol. Biotechnol. 2016, 26, 1891-1907. [CrossRef]

25. Hoffman, C.S. Preparation of yeast DNA. In Current Protocols in Molecular Biology; Ausubel, F., Brent, R., Kingston, R., Moore, D., Seidman, J., Smith, J., Struhl, K., Eds.; John Wiley \& Sons, Inc.: New York, NY, USA, 1997; pp. 13.11.1-13.11.4.

26. Kurtzman, C.P.; Robnett, C.J. Identification and Phylogeny of Ascomycetous Yeasts from Analysis of Nuclear Large Subunit (26S) Ribosomal DNA Partial Sequences. Antonie Van Leeuwenhoek 1998, 73, 331-371. [CrossRef]

27. Edgar, R.C. MUSCLE: Multiple Sequence Alignment with High Accuracy and High Throughput. Nucleic Acids Res. 2004, 32, 1792-1797. [CrossRef] [PubMed]

28. Kumar, S.; Stecher, G.; Li, M.; Knyaz, C.; Tamura, K. MEGA X: Molecular Evolutionary Genetics Analysis across Computing Platforms. Mol. Biol. Evol. 2018, 35, 1547-1549. [CrossRef] [PubMed]

29. Silva, R.; Aguiar, T.Q.; Domingues, L. Blockage of the Pyrimidine Biosynthetic Pathway Affects Riboflavin Production in Ashbya gossypii. J. Biotechnol. 2015, 193, 37-40. [CrossRef] [PubMed]

30. Ledesma-Amaro, R.; Serrano-Amatriain, C.; Jiménez, A.; Revuelta, J.L. Metabolic Engineering of Riboflavin Production in Ashbya gossypii through Pathway Optimization. Microb. Cell Fact. 2015, 14, 163. [CrossRef] [PubMed]

31. Grigoriev, I.V.; Nikitin, R.; Haridas, S.; Kuo, A.; Ohm, R.; Otillar, R.; Riley, R.; Salamov, A.; Zhao, X.; Korzeniewski, F.; et al. MycoCosm Portal: Gearing up for 1000 Fungal Genomes. Nucleic Acids Res. 2014, 42, D699-D704. [CrossRef]

32. Koonin, E.V.; Fedorova, N.D.; Jackson, J.D.; Jacobs, A.R.; Krylov, D.M.; Makarova, K.S.; Mazumder, R.; Mekhedov, S.L.; Nikolskaya, A.N.; Rao, B.S.; et al. A Comprehensive Evolutionary Classification of Proteins Encoded in Complete Eukaryotic Genomes. Genome Biol. 2004, 5, R7. [CrossRef]

33. Ferreira, D.; Nobre, A.; Silva, M.L.; Faria-Oliveira, F.; Tulha, J.; Ferreira, C.; Lucas, C. XYLH Encodes a Xylose/H+ Symporter from the Highly Related Yeast Species Debaryomyces fabryi and Debaryomyces hansenii. FEMS Yeast Res. 2013, 13, 585-596. [CrossRef]

34. Saier, M.H.; Reddy, V.S.; Moreno-Hagelsieb, G.; Hendargo, K.J.; Zhang, Y.; Iddamsetty, V.; Lam, K.J.K.; Tian, N.; Russum, S.; Wang, J.; et al. The Transporter Classification Database (TCDB): 2021 Update. Nucleic Acids Res. 2021, 49, D461-D467. [CrossRef]

35. Monteiro, P.T.; Oliveira, J.; Pais, P.; Antunes, M.; Palma, M.; Cavalheiro, M.; Galocha, M.; Godinho, C.P.; Martins, L.C.; Bourbon, N.; et al. YEASTRACT+: A Portal for Cross-Species Comparative Genomics of Transcription Regulation in Yeasts. Nucleic Acids Res. 2020, 48, D642-D649. [CrossRef]

36. Godinho, C.P.; Palma, M.; Oliveira, J.; Mota, M.N.; Antunes, M.; Teixeira, M.C.; Monteiro, P.T.; Sá-Correia, I. The N.C.Yeastract and CommunityYeastract Databases to Study Gene and Genomic Transcription Regulation in Non-Conventional Yeasts. FEMS Yeast Res. 2021, 21, foab045. [CrossRef]

37. Nordberg, H.; Cantor, M.; Dusheyko, S.; Hua, S.; Poliakov, I.S.; Shabalov, I.; Smirnova, T.; Grigoriev, I.V.; Dubchak, I. The Genome Portal of the Department of Energy Joint Genome Institute: 2014 Updates. Nucleic Acids Res. 2014, 42, D26-D31. [CrossRef] [PubMed]

38. Satianpakiranakorn, P.; Khunnamwong, P.; Limtong, S. Yeast Communities of Secondary Peat Swamp Forests in Thailand and Their Antagonistic Activities against Fungal Pathogens Cause of Plant and Postharvest Fruit Diseases. PLoS ONE 2020, 15, e0230269. [CrossRef] [PubMed]

39. Boonmak, C.; Khunnamwong, P.; Limtong, S. Yeast Communities of Primary and Secondary Peat Swamp Forests in Southern Thailand. Antonie Van Leeuwenhoek 2020, 113, 55-69. [CrossRef] [PubMed]

40. Carvalho, F.P.; Souza, A.C.; Magalhães-Guedes, K.T.; Dias, D.R.; Silva, C.F.; Schwan, R.F. Yeasts Diversity in Brazilian Cerrado Soils: Study of the Enzymatic Activities. Afr. J. Microbiol. Res. 2013, 7, 4176-4190. [CrossRef]

41. Worst, D.J.; Gerrits, M.M.; Vandenbroucke-Grauls, C.M.J.E.; Kusters, J.G. Helicobacter pylori RibBA-Mediated Riboflavin Production Is Involved in Iron Acquisition. J. Bacteriol. 1998, 180, 1473. [CrossRef]

42. Crossley, R.A.; Gaskin, D.J.H.; Holmes, K.; Mulholland, F.; Wells, J.M.; Kelly, D.J.; Van Vliet, A.H.M.; Walton, N.J. Riboflavin Biosynthesis Is Associated with Assimilatory Ferric Reduction and Iron Acquisition by Campylobacter jejuni. Appl. Environ. Microbiol. 2007, 73, 7819-7825. [CrossRef]

43. Philpott, C.C.; Protchenko, O. Response to Iron Deprivation in Saccharomyces cerevisiae. Eukaryot. Cell 2008, 7, 20. [CrossRef]

44. Holmes-Hampton, G.P.; Jhurry, N.D.; McCormick, S.P.; Lindahl, P.A. Iron Content of Saccharomyces cerevisiae Cells Grown under Iron-Deficient and Iron-Overload Conditions. Biochemistry 2013, 52, 105. [CrossRef]

45. Ramos-Alonso, L.; Romero, A.M.; Martínez-Pastor, M.T.; Puig, S. Iron Regulatory Mechanisms in Saccharomyces cerevisiae. Front. Microbiol. 2020, 11, 2222. [CrossRef]

46. Schwechheimer, S.K.; Becker, J.; Peyriga, L.; Portais, J.C.; Wittmann, C. Metabolic Flux Analysis in Ashbya gossypii Using 13CLabeled Yeast Extract: Industrial Riboflavin Production under Complex Nutrient Conditions. Microb. Cell Fact. 2018, 17, 162. [CrossRef] 
47. Villas-Bôas, S.G.; Åkesson, M.; Nielsen, J. Biosynthesis of Glyoxylate from Glycine in Saccharomyces cerevisiae. FEMS Yeast Res. 2005, 5, 703-709. [CrossRef] [PubMed]

48. Grant, C.M.; MacIver, F.H.; Dawes, I.W. Glutathione Synthetase Is Dispensable for Growth under Both Normal and Oxidative Stress Conditions in the Yeast Saccharomyces cerevisiae Due to an Accumulation of the Dipeptide Gamma-Glutamylcysteine. Mol. Biol. Cell 1997, 8, 1699-1707. [CrossRef] [PubMed]

49. Sinclair, D.A.; Dawes, I.W. Genetics of the Synthesis of Serine from Glycine and the Utilization of Glycine as Sole Nitrogen Source by Saccharomyces cerevisiae. Genetics 1995, 140, 1213-1222. [CrossRef] [PubMed]

50. Martins, L.C.; Palma, M.; Angelov, A.; Nevoigt, E.; Liebl, W.; Sá-Correia, I. Complete Utilization of the Major Carbon Sources Present in Sugar Beet Pulp Hydrolysates by the Oleaginous Red Yeasts Rhodotorula toruloides and R. mucilaginosa. J. Fungi 2021, 7, 215. [CrossRef]

51. Wohlbach, D.J.; Kuo, A.; Sato, T.K.; Potts, K.M.; Salamov, A.A.; LaButti, K.M.; Sun, H.; Clum, A.; Pangilinan, J.L.; Lindquist, E.A.; et al. Comparative Genomics of Xylose-Fermenting Fungi for Enhanced Biofuel Production. Proc. Natl. Acad. Sci. USA 2011, 108, 13212-13217. [CrossRef]

52. Shen, X.X.; Opulente, D.A.; Kominek, J.; Zhou, X.; Steenwyk, J.L.; Buh, K.V.; Haase, M.A.B.; Wisecaver, J.H.; Wang, M.; Doering, D.T.; et al. Tempo and Mode of Genome Evolution in the Budding Yeast Subphylum. Cell 2018, 175, 1533-1545.e20. [CrossRef]

53. Haase, M.A.B.; Kominek, J.; Langdon, Q.K.; Kurtzman, C.P.; Hittinger, C.T. Genome Sequence and Physiological Analysis of Yamadazyma laniorum f.a. sp. nov. and a Reevaluation of the Apocryphal Xylose Fermentation of Its Sister Species, Candida tenuis. FEMS Yeast Res. 2017, 17, fox019. [CrossRef]

54. Tatusov, R.L.; Fedorova, N.D.; Jackson, J.D.; Jacobs, A.R.; Kiryutin, B.; Koonin, E.V.; Krylov, D.M.; Mazumder, R.; Mekhedov, S.L.; Nikolskaya, A.N.; et al. The COG Database: An Updated Version Includes Eukaryotes. BMC Bioinform. 2003, 4, 41. [CrossRef]

55. Sa, N.; Rawat, R.; Thornburg, C.; Walker, K.D.; Roje, S. Identification and Characterization of the Missing Phosphatase on the Riboflavin Biosynthesis Pathway in Arabidopsis thaliana. Plant J. 2016, 88, 705-716. [CrossRef]

56. Skrzypek, M.S.; Binkley, J.; Binkley, G.; Miyasato, S.R.; Simison, M.; Sherlock, G. The Candida Genome Database (CGD): Incorporation of Assembly 22, Systematic Identifiers and Visualization of High Throughput Sequencing Data. Nucleic Acids Res. 2017, 45, D592. [CrossRef]

57. Liu, S.; Hu, W.; Wang, Z.; Chen, T. Production of Riboflavin and Related Cofactors by Biotechnological Processes. Microb. Cell Fact. 2020, 19, 31. [CrossRef] [PubMed]

58. Dmytruk, K.; Lyzak, O.; Yatsyshyn, V.; Kluz, M.; Sibirny, V.; Puchalski, C.; Sibirny, A. Construction and Fed-Batch Cultivation of Candida famata with Enhanced Riboflavin Production. J. Biotechnol. 2014, 172, 11-17. [CrossRef]

59. Dmytruk, K.V.; Voronovsky, A.Y.; Sibirny, A.A. Insertion Mutagenesis of the Yeast Candida famata (Debaryomyces hansenii) by Random Integration of Linear DNA Fragments. Curr. Genet. 2006, 50, 183-191. [CrossRef] [PubMed]

60. Chen, C.; Noble, S.M. Post-Transcriptional Regulation of the Sef1 Transcription Factor Controls the Virulence of Candida albicans in Its Mammalian Host. PLoS Pathog. 2012, 8, e1002956. [CrossRef] [PubMed]

61. Chen, C.; Pande, K.; French, S.D.; Tuch, B.B.; Noble, S.M. An Iron Homeostasis Regulatory Circuit with Reciprocal Roles in Candida albicans Commensalism and Pathogenesis. Cell Host Microbe 2011, 10, 118-135. [CrossRef] [PubMed]

62. Singh, R.P.; Prasad, H.K.; Sinha, I.; Agarwal, N.; Natarajan, K. Cap2-HAP Complex Is a Critical Transcriptional Regulator That Has Dual but Contrasting Roles in Regulation of Iron Homeostasis in Candida albicans. J. Biol. Chem. 2011, 286, 25154-25170. [CrossRef]

63. Sibirny, A.A.; Boretsky, Y.R. Pichia guilliermondii. In Yeast Biotechnology: Diversity and Applications; Springer: Berlin/Heidelberg, Germany, 2009; pp. 113-134. ISBN 9781402082917.

64. Tsyrulnyk, A.O.; Andreieva, Y.A.; Ruchala, J.; Fayura, L.R.; Dmytruk, K.V.; Fedorovych, D.V.; Sibirny, A.A. Expression of Yeast Homolog of the Mammal BCRP Gene Coding for Riboflavin Efflux Protein Activates Vitamin B2 Production in the Flavinogenic Yeast Candida famata. Yeast 2020, 37, 467-473. [CrossRef]

65. Enright, A.J.; Van Dongen, S.; Ouzounis, C.A. An Efficient Algorithm for Large-Scale Detection of Protein Families. Nucleic Acids Res. 2002, 30, 1575-1584. [CrossRef]

66. Reihl, P.; Stolz, J. The Monocarboxylate Transporter Homolog Mch5p Catalyzes Riboflavin (Vitamin B2) Uptake in Saccharomyces cerevisiae. J. Biol. Chem. 2005, 280, 39809-39817. [CrossRef]

67. Fourie, R.; Kuloyo, O.O.; Mochochoko, B.M.; Albertyn, J.; Pohl, C.H. Iron at the Centre of Candida albicans Interactions. Front. Cell. Infect. Microbiol. 2018, 8, 185. [CrossRef]

68. Duval, C.; Macabiou, C.; Garcia, C.; Lesuisse, E.; Camadro, J.; Auchère, F. The Adaptive Response to Iron Involves Changes in Energetic Strategies in the Pathogen Candida albicans. Microbiologyopen 2020, 9, e970. [CrossRef] [PubMed]

69. Yun, C.W.; Bauler, M.; Moore, R.E.; Klebba, P.E.; Philpott, C.C. The Role of the FRE Family of Plasma Membrane Reductases in the Uptake of Siderophore-Iron in Saccharomyces cerevisiae. J. Biol. Chem. 2001, 276, 10218-10223. [CrossRef]

70. Wang, T.P.; Quintanar, L.; Severance, S.; Solomon, E.I.; Kosman, D.J. Targeted Suppression of the Ferroxidase and Iron Trafficking Activities of the Multicopper Oxidase Fet3p from Saccharomyces cerevisiae. J. Biol. Inorg. Chem. 2003, 8, 611-620. [CrossRef] [PubMed]

71. Almeida, R.S.; Wilson, D.; Hube, B. Candida albicans Iron Acquisition within the Host. FEMS Yeast Res. 2009, 9, 1000-1012. [CrossRef] 
72. Weissman, Z.; Shemer, R.; Kornitzer, D. Deletion of the Copper Transporter CaCCC2 Reveals Two Distinct Pathways for Iron Acquisition in Candida albicans. Mol. Microbiol. 2002, 44, 1551-1560. [CrossRef]

73. Huffman, D.L.; O'Halloran, T.V. Energetics of Copper Trafficking between the Atx1 Metallochaperone and the Intracellular Copper Transporter, Ccc2. J. Biol. Chem. 2000, 275, 18611-18614. [CrossRef] [PubMed]

74. Dix, D.R.; Bridgham, J.T.; Broderius, M.A.; Byersdorfer, C.A.; Eide, D.J. The FET4 Gene Encodes the Low Affinity Fe(I1) Transport Protein of Saccharomyces cerevisiae. J. Biol. Chem. 1994, 269, 26092-26099. [CrossRef]

75. Heymann, P.; Ernst, J.F.; Winkelmann, G. Identification and Substrate Specificity of a Ferrichrome-Type Siderophore Transporter (Arn1p) in Saccharomyces cerevisiae. FEMS Microbiol. Lett. 2006, 186, 221-227. [CrossRef] [PubMed]

76. Kim, D.; Yukl, E.T.; Moënne-Loccoz, P.; Ortiz De Montellano, P.R. Fungal Heme Oxygenases: Functional Expression and Characterization of Hmx1 from Saccharomyces cerevisiae and CaHmx1 from Candida albicans. Biochemistry 2006, 45, 14772-14780. [CrossRef]

77. Weissman, Z.; Kornitzer, D. A Family of Candida Cell Surface Haem-Binding Proteins Involved in Haemin and Haemoglobin-Iron Utilization. Mol. Microbiol. 2004, 53, 1209-1220. [CrossRef]

78. Ror, S.; Panwar, S.L. Sef1-Regulated Iron Regulon Responds to Mitochondria-Dependent Iron-Sulfur Cluster Biosynthesis in Candida albicans. Front. Microbiol. 2019, 10, 1528. [CrossRef] [PubMed]

79. Blazhenko, O.V. Glutathione Deficiency Leads to Riboflavin Oversynthesis in the Yeast Pichia guilliermondii. Curr. Microbiol. 2014, 69, 10-18. [CrossRef] [PubMed]

80. Palma, M.; Goffeau, A.; Spencer-Martins, I.; Baret, P.V. A Phylogenetic Analysis of the Sugar Porters in Hemiascomycetous Yeasts. J. Mol. Microbiol. Biotechnol. 2007, 12, 241-248. [CrossRef] [PubMed]

81. Baruffini, E.; Goffrini, P.; Donnini, C.; Lodi, T. Galactose Transport in Kluyveromyces lactis: Major Role of the Glucose Permease Hgt1. FEMS Yeast Res. 2006, 6, 1235-1242. [CrossRef] 